Uluslararası Sosyal Bilgilerde Yeni Yaklaşımlar Dergisi, 2021, 5(1), 152-176

International Journal of New Approaches in Social Studies, 2021, 5(1), 152-176

\title{
Türkiye'de Sosyal Bilgiler Eğitimi Alanında Hazırlanan Tarih Konulu Lisansüstü Tezlerdeki Eğilimler: Bir Meta- Sentez Çalışması
}

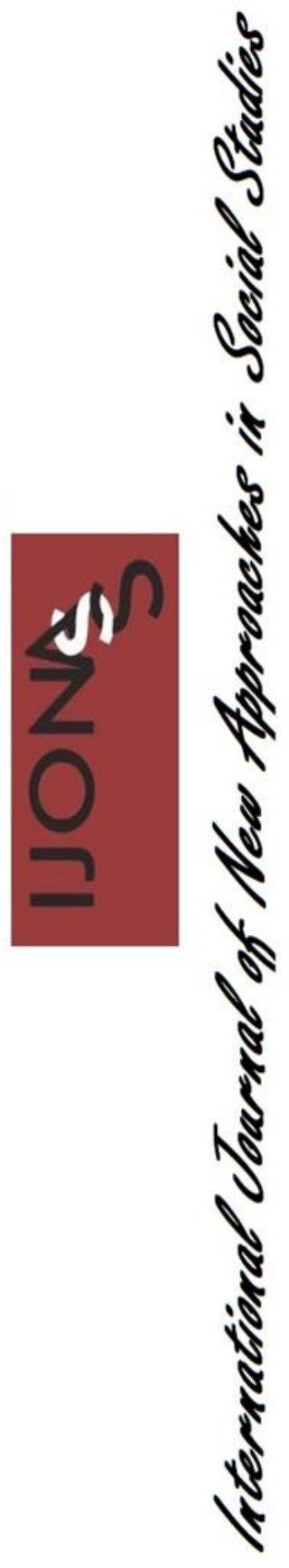

\author{
Filiz ZAYIMOĞLU ÖZTÜRK ${ }^{1 *}$ (10) \& Cenap SIĞNAKTEKIN
}

Gönderilme Tarihi: 06 Şubat $2021 \quad$ Kabul Tarihi: 25 Mayıs 2021

DOI: $10.38015 /$ sbyy. 875796

\begin{abstract}
$\ddot{O}_{z:}$
Bu çalışmanın amacı, Türkiye'de sosyal bilgiler eğitimi içerisinde tarih ve tarih ögretimi konuları bağlamında yapılmış lisansüstü tez çalışmalarını ve bu tezlerdeki eğilimleri çeşitli değişkenler açısından kapsamlı bir şekilde incelemektir. Bu amaç doğrultusunda çalışmada nitel araştırma yaklaşımı kullanılmıştır. İncelenen 72 tez YÖK ulusal tez merkezinden elde edilmiştir. Verilerin analiz sürecinde öncelikle araştırmacılar tarafindan her bir teze ait araştırma alt sorularını içeren bir künye belgesi/tez tanımlama kataloğu oluşturulmuştur. Veri analizinde MAXQDA 2020 nitel veri analiz programından yararlanılarak veriler alt amaçlar doğrultusunda tema ve kategorilere dönüştürülerek kodlanmış ve içerik analizi yapılmıştır. Tezler, yıl ve tez türü değişkenlerine göre, üniversite değişkenine göre, ele alınan konulara göre, amaçlarına göre, kullanılan araştırma yöntemlerine göre, çalışma grubu/örneklem açısından, veri toplama araçları açısından, verilerin analizinde kullanılan yöntemlere göre ve geliştirilen önerilere göre incelenmiştir. Incelenen lisansüstü tezlerde en fazla tez çalışmasının 2019 yılında yapıldı̆̆ı, konuların öğretiminde çoğunlukla öğretmen görüşlerinin tercih edildiği, tezlerin yöntem açısından oldukça yetersiz olduğu ve önemli bir kısmında yöntemin bulunmadı $\breve{g}$, tez sayısının en çok olduğu üniversitelerin Marmara, Gazi ve Niğde üniversiteleri olduğu, en çok nitel araştırma desenlerinin ve görüşme formunun kullanıldığı ve genellikle ögretmenlere öneriler getirildiği görülmüştür.
\end{abstract}

Anahtar Kelimeler: Sosyal bilgiler, tarih ögretimi, tarih, meta-sentez.

\begin{abstract}
:
The purpose of this study is to examine graduate theses and trends in them comprehensively in terms of different variables conducted in social studies education in the context of history and history education in Turkey. For this purpose, a qualitative research approach was used in the study. The examined 72 theses were obtained from YÖK national thesis center. In data analysis, using the MAXQDA 2020 qualitative data analysis program, the data was transformed into themes and categories in line with subpurposes, coded and content analysis was performed. Theses were analyzed according to the variables of year and thesis type, university variable, the subjects discussed, purposes, the research methods used, the study group / sample, the data collection tools, the methods used in the analysis of the data and the recommendations. In the postgraduate theses examined, it was seen that the most theses studies were conducted in 2019, teachers' opinions were mostly preferred in teaching the subjects, theses are quite insufficient in terms of methodology and most of them do not have this section, Marmara, Gazi and Niğde universities were the universities with the highest number of
\end{abstract}

${ }^{1}$ Ordu Üniversitesi, Türkiye, ORCID ID: 0000-0002-9917-5841

${ }^{2}$ Ordu Üniversitesi, Türkiye, ORCID ID: 0000-0003-2394-5130

"SorumluYazar (Corresponding Author): zayimogluf@ hotmail.com 
theses, qualitative research designs and interview forms were used the most and suggestions were generally made to teachers.

Keywords: Social studies, history, history teaching, meta-synthesis.

\section{GíRiș}

Multidisipliner bir alan olan sosyal bilgiler eğitimi içerisinde tarih konuları ve bunların öğretiminin önemli bir yer tuttuğu söylenebilir. Tarih konuları, sosyal bilgiler öğretim programlarının bel kemiği olarak kabul edilmektedir. $\mathrm{Bu}$ durum sosyal bilgiler öğretim programlarında tarih ağırlıklı tasarımların ortaya çıkmasını da beraberinde getirmektedir. $\mathrm{Bu}$ doğrultuda ülkemizdeki sosyal bilgiler öğretim programını oluşturan sosyal bilim disiplinleri içinde tarih konularının özel bir konuma sahip olduğu bilinmektedir (Ata, 2009). Sosyal bilgileri oluşturan temel disiplinler içinde de, tarih ile ilgili olan ve tarihin kapsamına giren birçok konu bulunmakta, sosyal bilgiler dersinde birçok konuda; mutlaka tarih ile ilgili bir bağlantı bulunabilmektedir (Turan \& Ulusoy, 2011). Ülkemizde sosyal bilgiler eğitimi alanında birçok bilim insanı tarafından yapılan araştırmalar da sosyal bilgiler eğitimi ile tarih bağlantısını ortaya koymaktadır (Ata, 2007; Akdağ, 2009; Öztürk \& Dilek, 2005; Turan \& Akdă̆, 2017).

Tarih öğretimi, tarih biliminin ürettiği verilerin toplumlarla buluşması ve toplumların bilinçlenmesinin sağlanması noktasında ön plana çıkan bir alandır. Bireylerde ahlaki gelişimin sağlanması, demokratik yaşam becerilerinin kazanılması, milli kimlik gelişiminin sağlanması, geçmişin öğrenilerek geçmişten ders alınması, içinde bulunulan zaman diliminde yaşanan sorunların anlamlandırılması ve yorumlanması gibi çeşitli amaçlarla tarih öğretimi yapılmaktadır (Demircioğlu, 2010). Tarih konuları öğretilirken öğrencilere milli kimlik kazandırıp kültürel mirasın gelecek nesillere aktarılması misyonu ön plana çıkmaktadır. $\mathrm{Bu}$ misyon doğrultusunda öğrencilerden geçmişi sorgulamaları ve gelecek hakkında öngörüde bulunmaları beklenmektedir (Dilek, 2002).

Bütün disiplinlerde olduğu gibi sosyal bilgiler eğitimi alanında da bilimsel çalışmaların belirli aralıklarla ve kapsamlı bir şekilde incelenmesi, alanın genel görünümünün ortaya çıkması açısından önemlidir. Alanyazın inceleme çalışmalarıyla bu alanda yapılan çalışmaların derinliği ve çeşitliği, araştırmaların çeşitli özellikleri, çalışılan konular; kullanılan yöntem ve teknikler, hâkim bakış açısı ve bunun tarihsel süreçte geçirdiği değişim dönüşüm gibi hususlar üzerine kapsamlı inceleme ve bütüncül değerlendirme ortaya çıkabilmektedir (Cücük, 2017).

Ülke gereksinimlerine yönelik düzenlemelerin yapılması, ilgili alanın geliştirilmesi ve öğretim elemanı kadrolarının yetiştirilmesi amacıyla herhangi bir bilim dalında yüksek lisans veya doktora öğrenimi yaparak uzmanlaşmaya olanak sağlayan ve en üst öğrenim seviyesi olarak ifade edilen lisansüstü eğitimin nihai ürünü olan tezler önemlidir (Coşkun \& diğ., 2014). Üstüner ve Cömert (2008), hazırlanan lisansüstü tezlerin özellikleri ve içeriği hakkında bilgi sahibi olunmasının ilgili bilim dalının nasıl geliştiği hakkında bilgi vereceğini belirtmektedir. $\mathrm{Bu}$ alanda yapılmış çalışmalar incelediğinde ise; Türkiye'de sosyal bilgiler ve tarih eğitimi ile ilgili yapılmış lisansüstü tezlerin değerlendirildiği (Hayta \& diğ., 2020), 1999-2019 yılları arasında sosyal bilgilerde tarih ile ilgili konuların öğretimi üzerine yapılan tezlerin incelendiği çalışmalara (Çırak, 2020) rastlanmaktadır.

Literatürdeki sosyal bilgiler eğitimi alanındaki meta sentez çalışmaları incelendiğinde; tarih öğretimi alanındaki tezlerin incelendiği (Kaymakc1, 2017), sosyal bilgiler eğitiminde coğrafya 
konulu lisansüstü tezlerin incelediği (Öner \& Öner, 2017), vatandaşlık ve insan hakları eğitimi alanı lisansüstü tezlerin ele alındığı (Gürdoğan-Bayır, Kılıç \& Balbağ,2018; Kayaalp \& Karameşe, 2020; Sönmez, Merey \& Kaymakc1, 2009), sosyal bilgiler ve karşılaştırmalı eğitim alanı lisansüstü tezlerinin incelendiği (Özkaral \& Mentiş-Taş, 2017) ve son olarak sosyal bilgiler eğitimi alanına yönelik lisansüstü tezler çeşitli araştırmalarda (Aksoy \& diğ., 2009; Canbulat, Avcı \& Sipahi, 2016; Dilek, Baysan \& Öztürk, 2018; Geçit \& Kartal, 2010; OğuzHaçat \& Demir, 2018; Oruç \& Ulusoy, 2008) ele alındığı görülmüştür. Sosyal bilgiler eğitimi alanında nitelikli akademisyen ve araştırmacıların yetiştirilmesi ve kaliteli çalışmaların ortaya çıkarılması açısından yüksek lisans ve doktora düzeyinde hazırlanan tezlerin belli zaman aralıkları ile incelenerek eğilimlerin ortaya konması, gelecek çalışmalar için projeksiyon oluşturma ve sonraki çalışmalar için öneriler sunma açısından önemlidir. Çalışma sonuçlarının, sosyal bilgiler eğitiminde tarih öğretimi alanında Türkiye'de yapılan tezleri çeşitli özellikleri açısından inceleyerek bir perspektif oluşturması, yapılacak yeni çalışmalar için ihtiyaç duyulan araştırma konu ve yöntemlerinin belirlenmesi ve farklı fikirlerin ortaya konmasında yeni araştırmalara katkı sağlayacağı düşünülmektedir.

\section{Araştırmanın Amacı}

Bu çalışmanın amacı, Türkiye'de sosyal bilgiler eğitimi içerisinde tarih ve tarih eğitimi konuları bağlamında yapılmış lisansüstü tez çalışmalarını ve bu tezlerdeki eğilimleri çeşitli değişkenler açısından kapsamlı bir şekilde incelemektir. Bu genel amaca bağlı olarak derinlemesine incelemeler yapabilmek için aşağıdaki sorulara cevaplar aranmıştır.

Sosyal bilgiler eğitimi alanında tarih ve tarih öğretimi üzerine yapılan tezlerde;

1. Y1l ve tez türü değişkenlerine göre gelişim süreci nasıldır?

2. Üniversite değişkenine göre gelişim süreci nasıldır?

3. Ele alınan konular nelerdir?

4. Amaçlar nasıldır?

5. Kullanılan araştırma yöntemleri nelerdir?

6. Çalışma grubu/örneklem nasıldır?

7. Kullanılan veri toplama araçları nelerdir?

8. Verilerin analizinde kullanılan yöntemler nelerdir?

9. Ulaşılan sonuçlar nasıldır?

10. Geliştirilen öneriler nelerdir?

\section{YÖNTEM}

$\mathrm{Bu}$ araştırmada, çalışmanın amacına uygun olarak, meta-sentez çalışması kullanılmıştır. Metasentez, içerik analizi çalışmaları içerisinde yer alan bir çalışma olup aynı konu üzerinde yapılan çalışmaların tema veya ana şablonlar oluşturarak eleştirel bir bakış açısıyla yorumlanması ve sentezlenmesidir (Çalık \& Sözbilir, 2014). Bu çalışmada sosyal bilgiler alanında tarih konularında yapılan lisansüstü tezler meta-sentez çalışmasıyla temalaştırılmış ve eleştirel bir bakış açısıyla yorumlanmıştır.

\section{Verilerin Toplanmast}

Nitel araştırmalarda veri toplamak amacıyla doküman incelemesi, gözlem ve görüşme teknikleri kullanılmaktadır (Creswell, 2016). Bu araştırmada araştırmanın amacına uygun olarak bu tekniklerden biri olan doküman incelemesi kullanılmıştır. Doküman inceleme; doküman temini, temin edilen dokümanların anlaşılması, gerekirse dokümanların 
kategorilenmesi ve kullanılmasını gerektirir. Bu araştırmada belirtilen tekniğin sürecine uygun olarak sosyal bilgiler eğitimi alanında hazırlanmış olan tarih ve tarih öğretimi konulu lisansüstü tezler, YÖK ulusal tez veri merkezinden elde edilmiştir. Bu veri tabanından "sosyal bilgiler" ve "tarih" ve "tarih öğretimi" anahtar sözcükleri ile tarama yapılmıştır. Elde edilen dokümanlara araştırmaya dâhil etme ve ayırt etme işlemleri uygulanmıştır. Tezler incelendikten sonra sosyal bilgiler eğitimi kapsamında tarih ve tarih öğretimi konulu olduğu tespit edilen 72 lisansüstü tez araştırmaya dâhil edilmiştir. Araştırma kapsamında incelenen tezler Ek 1'de liste şeklinde sunulmuştur.

\section{Verilerin Analizi}

Verilerin analizinde ilk aşamayı künye belgesi olarak adlandırılan tez tanımlama kataloğunun hazırlanması oluşturmaktadır. $\mathrm{Bu}$ katalog araştırma alt amaçlarını içerecek şekilde araştırmacılar tarafından hazırlanmıştır. Tezler T1, T2, ... T72'ye kadar kodlanarak künye belgeleri oluşturularak liste hazırlanmıştır. 72 tez içerik analizi için MAXQDA 2020 nitel veri analiz programına T1'den T72'ye kadar oluşturulan künyeleri ile aktarılmıştır. Veriler üzerinde ilişkiler kurabilmek ve verileri açıklayabilecek kavramlara ulaşmak amacıyla içerik analizi yapılmıştır. Yıldırım \& Şimşek (2011) içerik analizinin temelini benzer verilerin belirli tema ve kavram çerçevesinde bir araya getirilmesinin ve okurun anlayabileceği şekilde yorumlanmasının oluşturduğunu belirtmektedir. Analiz programında veriler alt amaçlar doğrultusunda tema ve kategorilere dönüştürülerek detaylı kodlamalar yapılmıştır.

Sosyal bilgiler eğitiminde tarih konulu lisansüstü tezler üzerinden anlamlı bir sonuca ulaşmak için oluşturulan ana temalar üzerinde dikkatle çalışılmıştır. Oluşturulan temalar ve yapılan sınıflamalar titizlikle gözden geçirilmiştir. Tezler üzerinde bütüncül bir bakış açısı kazanıldıktan sonra elde edilen veriler alt amaçlara uygun olarak tablolar halinde bulgular bölümünde sunulmuştur.

\section{Geçerlik ve Güvenirlik Çalışmaları}

Nitel araştırmaların geçerlik çalışmaları uzman incelemesi başta olmak üzere çalışma grubuyla uzun süren etkileşim ve detaylı betimleme gibi süreçleri kapsamaktadır (Yıldırım \& Şimşek, 2011). Araştırmanın her aşamasında ve özellikle verilerin analizi aşamasında bir ölçme değerlendirme ve bir sosyal bilgiler eğitimi olmak üzere iki uzmandan görüş alınmıştır. $\mathrm{Bu}$ araştırmada incelenen 72 tez, tekrar tekrar okunmuş, kategorilere ayrılmış ve kategoriler her aşamada tekrar gözden geçirilmiştir.

Nitel araştırmaların güvenirlikleri için kullanılan tutarlık ve teyit incelemeleri (Yıldırım \& Şimşek, 2011) bu çalışma için de gerçekleştirilmiştir. Tutarlılık incelemesi için araştırma bulgularına göre oluşturulan kategoriler ve kategori içerisinde yer alan sınıflandırmanın kategoriye uygun olup olmadığını teyit etmek için uzman görüşü alınmıştır. Araştırmacılar ile uzman arasındaki görüş birliği ve görüş ayrılığını hesaplamak için Miles ve Huberman'ın (1994) güvenirlik = görüş birliği / görüş birliği + görüş ayrılığ 1 x 100 formülü kullanılmıştır. Yapılan güvenilirlik analizi sonucunda çalışmanın güvenilirliği \%91 hesaplanmıştır. Araştırma güvenilirliği için yapılan diğer bir işlem ise nitel analiz programı kullanıldığı için araştırma verilerine ve bulgularına her zaman erişim imkânının olmasıdır.

\section{BULGULAR}

$\mathrm{Bu}$ bölümde, araştırma alt amaçlarına ilişkin elde edilen bulgular ayrı başlıklarla tablolarla görselleştirilerek sunulmuş ve yorumlanmıştır. 


\section{Araştırmanın Birinci Alt Amacına İlişkin Bulgular ve Yorum}

"Sosyal bilgiler eğitimi alanında tarih ve tarih ögretimi konuları üzerine yapılmış lisansüstü tezlerin yıl ve tez türü değişkenlerine göre gelişim süreci nasıldır?” araştırma sorusuna ilişkin elde edilen bulgular tablo 1'de gösterilmiştir.

Tablo 1: Tezlerin Hazırlanma Y1lı ve Tez Türü Dağılımı

\begin{tabular}{llll}
\hline Yıl & Yüksek Lisans Tezleri & Doktora Tezleri & $\boldsymbol{f}$ \\
\hline 2000 & T1 & - & 1 \\
2002 & T2 & - & 1 \\
2003 & T3 & - & 1 \\
2006 & T4,T5,T6,T7 & T64 & 5 \\
2007 & T8, T9, T10 & T65, T66 & 5 \\
2008 & T11, T12, T13 & - & 3 \\
2009 & T14, T15, T16, T17, T18 & - & 5 \\
2010 & T19, T20, T21, T22 & - & 4 \\
2011 & T23, T24, T25 & T67, T68 & 5 \\
2012 & T26, T27, T28, T29 & - & 4 \\
2013 & T30, T31,T32 & T69 & 4 \\
2014 & T33, T34, T35 & - & 3 \\
2015 & T36, T37, T38 & T70 & 4 \\
2016 & T39, T40, T41,T42,43 & - & 5 \\
2017 & T44, T45 & T71 & 3 \\
2018 & T46 & - & 1 \\
2019 & T47,T48,T49,T50,T51,T52,T53,T54,T55T56,T57,T58,T & T72 & 18 \\
\hline TOPLAM & 59,T60,T61,T62,T63 & $\mathbf{9}$ & $\mathbf{7 2}$ \\
\hline
\end{tabular}

Tablo 1 incelendiğinde, sosyal bilgiler eğitimi alanında tarih konusu üzerine hazırlanmış lisansüstü tezlerin sayı olarak en fazla 2019 yılında (18 tez) olduğu, bunların 17'sinin yüksek lisans ve 1'inin doktora tezi olduğu görülmektedir. 2019 yılını 5'er tez ile 2016, 2011, 2009, 2007 ve 2006 y1lları takip etmektedir. Daha sonra, 4'er tez ile 2015, 2013, 2012 ve 2010 yılları gelmektedir. Sosyal bilgiler eğitimi içerisinde tarih konusu üzerine 2008, 2014 ve 2017 yıllarında 3'er tezin hazırlandığını görülmektedir. Sosyal bilgiler eğitiminde tarih konusu üzerine en az tezin yapıldığ y yllar olarak 1 tez ile 2018, 2002 ve 2000 yılları olduğu görülmektedir. Buna göre, 2000 yılından bu yana, incelenen konu ile ilgili her yıl en az 1 tez hazırlandığı ifade edilebilir. Bulgular, günümüze doğru gelindikçe, tarih içerikli hazırlanan sosyal bilgiler tez sayılarında da düzenli bir artış yaşandığını göstermektedir. Bu durumun sebepleri arasında, konunun öneminin artiyor olması varsayımının yanı sira, son yıllarda ülkemizde lisansüstü öğrenci ve çalışma sayılarındaki düzenli artışın da (Günay, 2018) önemli olduğu düşünülmektedir.

\section{Araştırmanın İkinci Alt Amacına İlişkin Bulgular ve Yorum}

"Sosyal bilgiler eğitimi alanında tarih ve tarih ögrretimi konularl üzerine yapılmış lisansüstü tezlerin üniversite değişkenine göre gelişim süreci nasıldır?" araştırma sorusuna ilişkin elde edilen bulgular tablo 2 'de gösterilmiştir. 
Tablo 2. Tezlerin Üniversitelere Göre Dağılımı

\begin{tabular}{|c|c|c|}
\hline Üniversiteler & Tezler & $f$ \\
\hline Marmara Üniversitesi & T2,T19,T18,T7,T11,T21,T34,T56,T61,T68,T10,T8 & 12 \\
\hline Gazi Üniversitesi & T6,T1,T16,T23,T62,T65,T66,T69,T14 & 9 \\
\hline Niğde Üniversitesi & $\mathrm{T} 52, \mathrm{~T} 17, \mathrm{~T} 28, \mathrm{~T} 44$ & 4 \\
\hline Çanakkale Üniversitesi & $\mathrm{T} 27, \mathrm{~T} 20, \mathrm{~T} 54$ & 3 \\
\hline Gaziosmanpaşa Üniversitesi & $\mathrm{T} 13, \mathrm{~T} 15, \mathrm{~T} 46$ & 3 \\
\hline Uşak Üniversitesi & $\mathrm{T} 31, \mathrm{~T} 45, \mathrm{~T} 71$ & 3 \\
\hline Sakarya Üniversitesi & T26,T48,T59 & 3 \\
\hline Selçuk Üniversitesi & T3,T5,T12 & 3 \\
\hline Furat Üniversitesi & $\mathrm{T} 9, \mathrm{~T} 4, \mathrm{~T} 25$ & 3 \\
\hline Balıkesir Üniversitesi & $\mathrm{T} 57, \mathrm{~T} 58$ & 2 \\
\hline Recep Tayip Erdoğan Üniversitesi & $\mathrm{T} 47, \mathrm{~T} 63$ & 2 \\
\hline Çukurova Üniversitesi & T22,T64 & 2 \\
\hline Muğla Sitk1 Koçman Üniversitesi & T36,T60 & 2 \\
\hline İstanbul Üniversitesi & T33,T35 & 2 \\
\hline Ağrı İbrahim Çeçen Üniversitesi & T39 & 1 \\
\hline Mehmet Akif Ersoy Üniversitesi & T38 & 1 \\
\hline Giresun Üniversitesi & $\mathrm{T} 37$ & 1 \\
\hline Hacettepe Üniversitesi & T67 & 1 \\
\hline Atatürk Üniversitesi & $\mathrm{T} 72$ & 1 \\
\hline Zirve Üniversitesi & T32 & 1 \\
\hline Adnan Menderes Üniversitesi & T55 & 1 \\
\hline Dokuz Eylül Üniversitesi & T30 & 1 \\
\hline Afyon Kocatepe Üniversitesi & T29 & 1 \\
\hline Uludağ Üniversitesi & T53 & 1 \\
\hline Aksaray Üniversitesi & $\mathrm{T} 24$ & 1 \\
\hline Bartın Üniversitesi & T50 & 1 \\
\hline Erciyes Üniversitesi & T49 & 1 \\
\hline Dumlupınar Üniversitesi & $\mathrm{T} 70$ & 1 \\
\hline Abant İzzet Baysal & $\mathrm{T} 43$ & 1 \\
\hline Kastamonu Üniversitesi & $\mathrm{T} 42$ & 1 \\
\hline İnönü Üniversitesi & T41 & 1 \\
\hline Çankırı Üniversitesi & $\mathrm{T} 40$ & 1 \\
\hline Toplam & & 72 \\
\hline
\end{tabular}

Tablo 2 incelediğinde, sosyal bilgiler eğitimi içerisinde tarih ve tarih eğitim konularında en fazla tezin Marmara Üniversitesi’nde (12) hazırlandığ ${ }_{1}$, burayı 9 tez ile Gazi üniversitesi ile 4 tez ile Niğde Üniversitesi'nin takip ettiği görülmektedir. Çanakkale, Gaziosmanpaşa, Uşak, Sakarya, Selçuk, Fırat Üniversitelerinde 3'er tez, Balıkesir, Recep Tayip Erdoğan, Çukurova, Muğla Sitkı Koçman, İstanbul Üniversitelerinde ise 2'şer tez görülmektedir. Araştırma konusuyla ilgili en az çalışmanın 1'er tez ile Ağrı İbrahim Çeçen, Mehmet Akif Ersoy, Giresun, Hacettepe, Atatürk, Zirve, Adnan Menderes, Dokuz Eylül, Afyon Kocatepe, Uludağ, Aksaray, Bartın, Erciyes, Dumlupınar, Abant İzzet Baysal, Kastamonu, İnönü, Çankırı Üniversiteleri olduğu görülmektedir. Yaylak (2019), Türkiye'de bulunan 129 devlet üniversitesinin 67'inde Sosyal Bilgiler Eğitimi Anabilim Dalı bulunduğu, bunların 60'nda lisans, 50'sinde yüksek lisans ve 19'unda da doktora programı bulunduğunu belirtmektedir. Bu çalışmadaki bulgularda 32 farklı üniversitede bu konu çalışıldığından hareketle, Türkiye'de lisansüstü seviyede eğitim yapan üniversitelerin hemen hemen yarıya yakınında, tarih konulu tezlerin çalışıldığ söylenebilir. 


\section{Araştırmanın Üçüncü Alt Amacına Illişkin Bulgular ve Yorum}

"Sosyal bilgiler eğitimi alanında tarih ve tarih ögretimi konuları üzerine yapılmış lisansüstü tezlerde ele alinan konular nelerdir? " araştırma sorusuna ilişkin elde edilen bulgular tablo 3 'te gösterilmiştir.

Tablo 3. Tezlerde Konu Dağılımı

\begin{tabular}{lll}
\hline Konular & Tezler & $f$ \\
\hline Sosyal bilgilerde tarih konularının öğretimi & T3,T16,T21,T27,T28,T38,T39,T40,T41, & 21 \\
& T44,T63,T69,T70,T1,T14,T15,T20,T23, \\
Sosyal bilgiler tarih konularının öğretiminde kullanılan & T24,T43,T9 & T32,T12,T45,T62,T57,T58,T37,T34,T53, \\
öğretim kuramları, yöntem ve teknikleri & T67, T56, T64 & \\
Sosyal bilgiler tarih konularında yer alan içerikler & T4,T5,T22,T30,T31,T60,T8,T51, T55 & 9 \\
Sosyal bilgiler tarih konularında kanıt temelli öğretim & T49,T65,T2,T6,T11,T36,T10, & 8 \\
& T6 & 6 \\
Tarihsel empati & T29,T47,T48,T50,T59,T61 & 4 \\
Tarih öğretiminde tarihi mekânların kullanımı & T72,T33,T18,T52 & 3 \\
Sözlü Tarih & T19,T66,T71 & 2 \\
Yerel tarih & T42,T13 & 2 \\
Tarihsel okuryazarlık & T7,T17 & 1 \\
Vatanseverlik & T46 & 1 \\
Tarih öğretiminde bilgi ve iletişim teknolojileri & T54 & $\mathbf{7 2}$ \\
\hline Toplam & & \\
\hline
\end{tabular}

Tablo 3'te, incelenen lisansüstü tezlerde en çok tercih edilen konunun 21 tez ile sosyal bilgiler tarih konularının öğretimi (program, ders, etkinlikler) üzerine olduğu görülmektedir. 12 tezin ise sosyal bilgiler tarih konularının öğretiminde kullanılan öğretim kuramları, yöntem ve teknikleri (çoklu zekâ, drama, oyunla öğretim, hikâye kullanımı, film ve dizi kullanımı, dizgeli öğretim, minyatür kullanımı, yapıcı öğrenme vb.) konu aldığı görülmektedir. Sosyal bilgiler tarih konularında kanıt temelli öğretim, sosyal bilgiler tarih konularında yer alan içerikleri (program, ders kitapları vb.) konu alan 9 tez, sosyal bilgiler tarih konularında kanıt temelli öğretimi konu alan 8 tez, sosyal bilgiler tarih konularında tarihsel empatinin kullanıldığı 6 tez, tarih öğretiminde tarihi mekânların kullanımı konusunda 4, sözlü tarih konusunda 3, tarihsel okuryazarlık/tarihi algilama becerisi ve yerel tarih konularında 2 tez ile tarih ve sosyal bilgiler eğitiminde bilgi ve iletişim teknolojisinin kullanımı, sosyal bilgiler ve tarih öğretmenlerinin yurt severlik tutumlarını konu alan 1'er adet tez olduğu görülmektedir. Bulgularda her ne kadar sosyal bilgiler eğitiminde tarih konularının öğretiminin çok yer tuttuğu görülse de, kanıt temelli tarih öğretim, tarihsel empati, sözlü tarih ve yerel tarih gibi konuların son yıllarda önemsendiği dikkat çekmektedir.

\section{Araşttrmanin Dördüncü Alt Amacına İlişsin Bulgular ve Yorum}

"Sosyal bilgiler eğitimi alanında tarih ve tarih ögretimi konuları üzerine yapılmış lisansüstü tezlerin amaçları nasıldır?" araştırma sorusuna ilişkin elde edilen bulgular tablo 4'te gösterilmiştir. 
Tablo 4. Tezlerin Amaçları

\begin{tabular}{|c|c|c|}
\hline Amaclar & Tezler & $f$ \\
\hline Sosyal bilgiler dersi tarih konularının öğretiminde & T24,T69,T67,T64,T9,T20,T28, & 20 \\
\hline kullanılabilecek model, yöntem ve yaklaşımların & $\mathrm{T} 58, \mathrm{~T} 53, \mathrm{~T} 57, \mathrm{~T} 68, \mathrm{~T} 10, \mathrm{~T} 45, \mathrm{~T} 6$, & \\
\hline incelenmesi & $\mathrm{T} 34, \mathrm{~T} 37, \mathrm{~T} 23, \mathrm{~T} 15, \mathrm{~T} 12, \mathrm{~T} 32$ & \\
\hline $\begin{array}{l}\text { Sosyal bilgiler ders kitaplarında yer alan tarih konularının } \\
\text { içerik ve işlenişlerinin incelenmesi }\end{array}$ & $\begin{array}{l}\mathrm{T} 60, \mathrm{~T} 55, \mathrm{~T} 40, \mathrm{~T} 30, \mathrm{~T} 27, \mathrm{~T} 22, \mathrm{~T} 42, \mathrm{~T} 13, \mathrm{~T} \\
6, \mathrm{~T} 26, \mathrm{~T} 44, \mathrm{~T} 43\end{array}$ & 12 \\
\hline $\begin{array}{l}\text { Sosyal bilgiler öğretiminde tarih konuları işlenişinde } \\
\text { ögretmen görüslerinin incelenmesi }\end{array}$ & $\begin{array}{l}\text { T39,T70,T25,T3,T1,T16,T21, } \\
\text { T38 }\end{array}$ & 8 \\
\hline $\begin{array}{l}\text { Sosyal bilgiler dersi tarih konularının öğretiminde tarihsel } \\
\text { kanıtların kullanımı ve etkililiğini incelemek }\end{array}$ & $\mathrm{T} 11, \mathrm{~T} 36, \mathrm{~T} 49, \mathrm{~T} 56, \mathrm{~T} 65, \mathrm{~T} 41, \mathrm{~T} 2$ & 7 \\
\hline $\begin{array}{l}\text { Sosyal bilgilerin ne olduğu, sosyal bilgiler ve tarih } \\
\text { ögretiminin amacı, önemi ve gelişimini incelemek }\end{array}$ & $\mathrm{T} 63, \mathrm{~T} 51, \mathrm{~T} 35, \mathrm{~T} 4, \mathrm{~T} 31$ & 5 \\
\hline $\begin{array}{l}\text { Tarihsel empatiye dayalı yapılan öğretimin öğrenci } \\
\text { başarısına, tutumuna ve kalıcılığa olan etkilerini } \\
\text { belirlemek }\end{array}$ & T47,T48,T50,T59,T61,T29 & 6 \\
\hline $\begin{array}{l}\text { Sosyal bilgiler dersinde tarihi mekân gezilerinin } \\
\text { ögrencilerin akademik başarılarına etkisini tespit etmek }\end{array}$ & $\mathrm{T} 52, \mathrm{~T} 33, \mathrm{~T} 18, \mathrm{~T} 72$ & 4 \\
\hline $\begin{array}{l}\text { Sosyal bilgiler ve tarih derslerinde sözlü tarih yöntemine } \\
\text { dayalı tarih öğretimini incelemek }\end{array}$ & $\mathrm{T} 66, \mathrm{~T} 71, \mathrm{~T} 19$ & 3 \\
\hline $\begin{array}{l}\text { Farklı ülkelere ait sosyal bilgiler eğitimi politikalarının } \\
\text { kazanım, içerik, ders bakımından karşılaştırılması }\end{array}$ & $\mathrm{T} 5, \mathrm{~T} 8$ & 2 \\
\hline $\begin{array}{l}\text { İlköğretim sekizinci sınıf öğrencilerinin tarihsel } \\
\text { okuryazarlık beceri/durum seviyelerini belirlemek }\end{array}$ & $\mathrm{T} 17, \mathrm{~T} 7$ & 2 \\
\hline $\begin{array}{l}\text { Sosyal bilgiler ve tarih öğretmenlerinin yurtseverlik ve } \\
\text { eğitimi hakkındaki tutumlarını ortaya koymak }\end{array}$ & $\mathrm{T} 14, \mathrm{~T} 46$ & 2 \\
\hline $\begin{array}{l}\text { Görme engelli tarih ve sosyal bilgiler öğretmenlerinin tarih } \\
\text { ve sosyal bilgiler eğitiminde bilgi ve iletişim } \\
\text { teknolojilerini kullanma stratejilerini incelemek }\end{array}$ & T54 & 1 \\
\hline Toplam & & 72 \\
\hline
\end{tabular}

Tablo 4'te, incelenen lisansüstü tezlerde temel amaç olarak 30 tez ile sosyal bilgiler tarih konularının öğretiminde kullanılabilecek model, yöntem ve yaklaşımların incelenmesini konu almaktadır. Görme engelli tarih ve sosyal bilgiler ögretmenlerinin tarih ve sosyal bilgiler eğitiminde bilgi ve iletişim teknolojilerini kullanma stratejileri 1 tez ile en az benimsenen amaç olmuştur. Çalışmaların amaçları arasında; 12 tez ile sosyal bilgiler ders kitaplarında yer alan tarih konularının içerik ve işlenişlerinin incelenmesi, 8 tez ile sosyal bilgiler öğretiminde tarih konularının işlenişinde öğretmen görüş̧lerinin incelenmesi, 7 tez ile sosyal bilgiler dersi tarih konularının öğretiminde tarihsel kanıtların etkililiğinin incelenmesi 6 tez ile tarihsel empatiye dayalı yapılan öğretimin öğrenci başarısına tutumuna ve kalıcılığa olan etkilerinin belirlenmesi, 5 tez ile sosyal bilgilerin ne olduğu, sosyal bilgiler ve tarih öğretiminin amacı, önemi ve gelişiminin incelenmesi, 4 tez ile sosyal bilgiler dersinde tarihi mekân gezilerinin öğrencilerin akademik başarılarına etkisinin tespit edilmesi, 3 tez ile sosyal bilgiler ve tarih derslerinde sözlü tarih yöntemine dayalı tarih öğretiminin incelenmesi gibi amaçlar bulunduğu görülmektedir.

\section{Araşstrmanın Beşinci Alt Amacına İliş̧in Bulgular ve Yorum}

"Sosyal bilgiler eğitimi alanında tarih ve tarih öğretimi konuları üzerine yapılmış lisansüstü tezlerde kullanılan araştırma yöntemleri nelerdir?" araştırma sorusuna ilişkin elde edilen bulgular tablo 5 'te gösterilmiş̧ir. 
Tablo 5. Tezlerde Kullanılan Yöntemler

\begin{tabular}{llc}
\hline Yöntem & Tezler & $f$ \\
\hline Nitel & T13,T14,T16,T69,T10,T7,T11,T12,T17,T18,T19,T20,T21,T26,T27, & 32 \\
& T33,T38,T39,T43,T44,T50,T53,T59,T60,T61,T63,T64,T67,T68, T71,T8,T6 & \\
Nicel & T15,T23,T25,T34,T37,T41,T48,T55,T46 & 9 \\
Karma & T10,T66,T24,T31,T36,T42,T47,T49,T56,T62,T65,T70,T72,T54, T45, T29 & 16 \\
Belirtilmemiş & T2,T58,T1,T51,T28,T4,T5,T9,T3,T30,T32,T35,T40,T52,T57 & 15 \\
\hline Toplam & & $\mathbf{7 2}$ \\
\hline
\end{tabular}

Tablo 5'te, incelenen lisansüstü tezlerde en fazla kullanılan araştırma yöntemi olarak 32 tezde nitel araştırma yaklaşımı kullanırken 9 tezde ise nicel araştırma yöntemlerinin tercih edildiği görülmektedir. 16 tezde karma araştırma yöntemi kullanılmıştır. 15 tezde ise araştırmanın yöntem bölümünde araştırma yöntemiyle ilgili bilgi verilmediği görülmüş ve "belirtilmemiş" kategorisinde sunulmuştur. Bu oranın yüksek olması dikkate değer ve olumsuz bir durum olarak değerlendirilmektedir. Araştırmacıların, yöntemde belirtilen verilerden yola çıkarak tezleri herhangi bir kategori altında sınıflandırmamalarının sebebi, birçok araştırmada yöntem ile ilgili sorunlara özellikle dikkat çekmek istemelerinden kaynaklanmaktadır.

\section{Araştırmanın Altıncı Alt Amacına İlişkin Bulgular ve Yorum}

"Sosyal bilgiler ĕgitimi alanında tarih ve tarih ögrretimi konularl üzerine yapılmış lisansüstü tezler çalışma grubu/örneklem açısından nasıldır?" araştırma sorusuna ilişkin elde edilen bulgular tablo 6'da gösterilmiştir.

Tablo 6. Tezlerde Çalışma Grubu/Örneklem

\begin{tabular}{llc}
\hline Çalışma Grubu/Örneklem & Tezler & $f$ \\
\hline Sosyal bilgiler öğretmeleri & T21,T46,T43,T53,T13,T40,T28,T49,T14, & 19 \\
& T27,T45,T70,T25,T39,T41,T44,T63,T55, T72 & 18 \\
& T7,T34,T23,T24,T29,T36,T47,T48,T50, & 11 \\
6.sınıf öğrencileri & T56,T57,T65,T66,T68,T61,T16,T59,T9 & 11 \\
Ders kitapları, program vb. dokümanlar & T57,T31,T49,T71,T10,T32,T52,T62,T1, T45,T15 & 8 \\
4.sınıf öğrencileri & T8,T30,T18,T6,T51,T5,T4,T22,T60,T51, T33,T35 & 5 \\
5.sinıf öğrencileri & T2,T24,T11,T67,T64,T12,T58,T37 & 2 \\
8.sinıf öğrencileri & T57,T19,T42,T2,T20 & 2 \\
Sinıf öğretmenleri & T17,T31 & 1 \\
Tarih öğretmenleri & T38,T2 & 1 \\
Görme engelli sosyal bilgiler öğretmenleri & T69 T54 & 1 \\
İlköğretim öğretmenleri & T3 & 1 \\
Lise öğrencileri & T40 & 1 \\
Okul öncesi & T26 & $\mathbf{8 1}$ \\
\hline Toplam & & \\
\hline
\end{tabular}

Tablo 6, sosyal bilgiler eğitimi alanında tarih ve tarih öğretimi konuları üzerine yapılmış lisansüstü tezlerde çalışma grubu/örneklem açısından incelendiğinde; frekans sayısının 81 olduğu görülmektedir. Bunun temel nedeni incelenen tezlerin konuları gereği birden fazla grupla çalışmayı gerektirmesinden kaynaklanmaktadır. Örneğin; T2 kodlu tez "sosyal bilgiler dersi tarih konularının öğretiminde tarihsel kanıtların etkililiğini sınıf öğretmenlerinin görüşleri ve sınıf içi uygulamalara katkısını 4. ve 5. sınıf öğrencilerini gözlemleyerek" yaptığını belirtmiş ve bu araştırma kapsamında üç farklı kategoride yer almıştır. Çalışma grubu kategorisine en fazla 19 tez ile sosyal bilgiler öğretmenlerinin, daha sonra da 18 tez ile 7 . sinıf öğrencilerinin tercih edildiği görülmektedir. Bu listeyi 11 tez ile 6 . sınıf öğrencileri, 8 tez ile 4 . sinıf öğrencileri takip etmektedir. 5 tez ile 5. sınıf öğrencileri, 2'şer tez ile 8 . sınıf öğrencileri, sınıf öğretmenleri katılımcı olarak yer almıştır. Araştırma sorusu kapsamında en az tercih edilen grupların ise 1'er 
tez ile okul öncesi, lise öğrencileri, ilköğretim öğretmenleri, görme engeli sosyal bilgiler ve tarih öğretmenleri olduğu görülmektedir. Doküman incelemesinin yapıldığ 11 tezde ise, yöntem gereği ders kitapları, öğretim programı gibi dokümanlar kullanılmıştır.

\section{Araştırmanın Yedinci Alt Amacına İlişkin Bulgular ve Yorum}

"Sosyal bilgiler eğitimi alanında tarih ve tarih ögretimi konuları üzerine yapılmış lisansüstü tezlerde kullanılan veri toplama araçları nelerdir?" araştırma sorusuna ilişkin elde edilen bulgular tablo 7'de gösterilmiştir.

Tablo 7. Tezlerde Veri Toplama Araçları

\begin{tabular}{lll}
\hline Veri toplama araçları & Tezler & $f$ \\
\hline Görüşme formu & T11,T12,T17,T20,T38,T42,T43,T44,T46,T47,T54, & 15 \\
& T59,T69,T70,T71 & 12 \\
Doküman taramas1 & T4,T6,T8,T9,T22,T30,T33,T35,T51,T60,T56,T5 & 11 \\
Başarı testi & T15,T21,T23,T34,T48,T52,T55,T61, T62,T58, T57 & 6 \\
Gözlem, görüşme formu, doküman taramas1 & $\mathrm{T} 10, \mathrm{~T} 19, \mathrm{~T} 26, \mathrm{~T} 40, \mathrm{~T} 63, \mathrm{~T} 68$ & 4 \\
Anket formu & $\mathrm{T} 3, \mathrm{~T} 28, \mathrm{~T} 32, \mathrm{~T} 41$ & 4 \\
Anket, görüşme formu & $\mathrm{T} 13, \mathrm{~T} 24, \mathrm{~T} 31, \mathrm{~T} 53$ & 3 \\
Anket formu-tutum ölçeği & $\mathrm{T} 14, \mathrm{~T} 49, \mathrm{~T} 64$ & 3 \\
Görüşme formu-doküman taramas1 & $\mathrm{T} 1, \mathrm{~T} 18, \mathrm{~T} 39$ & 3 \\
Görüşme formu-başarı testi & $\mathrm{T} 7, \mathrm{~T} 67, \mathrm{~T} 29$ & 2 \\
Gözlem-görüşme formu, başarı testi & $\mathrm{T} 50, \mathrm{~T} 66$ & 2 \\
Başarı testi, tutum ölçeği, doküman taramas1 & $\mathrm{T} 36, \mathrm{~T} 65$ & 2 \\
Görüşme-anket formu, doküman taramas1 & $\mathrm{T} 25, \mathrm{~T} 45$ & 1 \\
Başarı testi, doküman taramas1 & $\mathrm{T} 37$ & 1 \\
Gözlem, görüşme formu & $\mathrm{T} 27$ & 1 \\
Görüşme formu, tutum ölçeği & $\mathrm{T} 72$ & 1 \\
Anket formu, doküman taramas1 & $\mathrm{T} 16$ & 1 \\
Gözlem formu & $\mathrm{T} 2$ & $\mathbf{7 2}$ \\
\hline Toplam & & \\
\hline
\end{tabular}

Tablo 7'de, incelenen lisansüstü tezlerde en fazla kullanılan veri toplama araçları sırasıyla 15 tezde görüşme formu, 12 tezde doküman taraması, 10 tezde ise başarı testinin tercih edildiği görülmektedir. Bu listeyi 6'şar tez ile gözlem, görüşme formu, doküman taraması, 4'er tez ile anket formu-anket, görüşme formu, 3 'er tez ile anket formu-tutum ölçeği, görüşme formudoküman taraması, görüşme formu-başarı testi, 2'şer tez ile gözlem-görüşme formu, başarı testi, başarı testi-tutum ölçeği, doküman taraması, görüşme-anket formu, doküman taraması veri araçları izlemektedir. İncelenen lisansüstü tezlerden az kullanılan 1'er tez ile başarı testidoküman taramas1, gözlem-görüşme formu, görüşme formu-tutum ölçeği, anket formudoküman taraması, gözlem formu veri toplama araçlarının kullanıldığı görülmektedir.

\section{Araştırmanın Sekizinci Alt Amacına İlişkin Bulgular ve Yorum}

"Sosyal bilgiler ĕgitimi alanında tarih ve tarih ögretimi konularl üzerine yapılmış lisansüstü tezlerde verilerin analizinde kullanilan yöntemler nelerdir?" araştırma sorusuna ilişkin elde edilen bulgular tablo 8'de gösterilmiştir. 
Tablo 8. Tezlerde Kullanılan Yöntemler

\begin{tabular}{|c|c|c|c|}
\hline \multicolumn{2}{|c|}{ Veri analizi } & \multirow{2}{*}{$\begin{array}{l}\text { Tezler } \\
\text { T33,T60 }\end{array}$} & \multirow{2}{*}{$\begin{array}{l}f \\
33\end{array}$} \\
\hline Nitel & Doküman analizi & & \\
\hline & İçerik ve Betimsel analiz & & \\
\hline & Betimsel analiz & $\mathrm{T} 17, \mathrm{~T} 20, \mathrm{~T} 21, \mathrm{~T} 27, \mathrm{~T} 38, \mathrm{~T} 39, \mathrm{~T} 43, \mathrm{~T} 50, \mathrm{~T} 51, \mathrm{~T} 5$ & \\
\hline & & 3,T59T61,T63,T69 & \\
\hline & İçerik analizi & $\mathrm{T} 12, \mathrm{~T} 19, \mathrm{~T} 44, \mathrm{~T} 45, \mathrm{~T} 64, \mathrm{~T} 70, \mathrm{~T} 72$ & \\
\hline & Betimsel, İçerik ve Söylem analizi & T11 & \\
\hline & Betimsel ve İçerik analizi & $\mathrm{T} 7, \mathrm{~T} 8, \mathrm{~T} 54, \mathrm{~T} 68, \mathrm{~T} 71$ & \\
\hline & Betimsel, İçerik ve Doküman analizi & $\mathrm{T} 10, \mathrm{~T} 67$ & \\
\hline & Nitel içerik çözümlemesi ve yorumsal analiz & $\mathrm{T} 26$ & \\
\hline \multirow[t]{6}{*}{ Nicel } & Tek yönlü varyans analizi (ANOVA) & T25,T58,T46 & 24 \\
\hline & T-testi & T34,T41,T1,T57,T9,T37 & \\
\hline & Mann whitney u testi & T52 & \\
\hline & Betimsel analiz (frekans ve yüzde) & $\begin{array}{l}\mathrm{T} 15, \mathrm{~T} 32, \mathrm{~T} 48, \mathrm{~T} 66, \mathrm{~T} 40, \mathrm{~T} 2, \mathrm{~T} 55, \mathrm{~T} 62, \mathrm{~T} 3, \mathrm{~T} 16, \\
\mathrm{~T} 13\end{array}$ & \\
\hline & Faktör analizi & T14 & \\
\hline & Çoklu Doğrusal Regresyon & $\mathrm{T} 23$ & \\
\hline \multirow[t]{5}{*}{ Karma } & $\begin{array}{l}\text { T-testi, Çift yönlü Varyans (Nicel)-Betimsel } \\
\text { analiz (Nitel) }\end{array}$ & $\mathrm{T} 42$ & 7 \\
\hline & T-testi (Nicel), Betimsel (Nitel) & T36 & \\
\hline & İçerik (Nitel), Betimsel (Nicel) & T31 & \\
\hline & NVIVO-7, T testi & T29 & \\
\hline & İçerik analizi (Nitel), Betimsel (Nicel) & T56, T65, T24 & \\
\hline \multicolumn{2}{|c|}{ Belirtilmemiş } & T4,T5,T22,T28,T30,T35,T49,T6 & 8 \\
\hline \multicolumn{2}{|c|}{ Toplam } & & 72 \\
\hline
\end{tabular}

Tablo 8'de, incelenen lisansüstü 33 tezde nitel veri analizi tekniği kullanılırken 24 tezde nicel veri analizi teknikleri tercih edilmiştir. Nitel ve nicel veri analizlerinin beraber kullanımına ise 7 tezde yer verildiği görülmüştür. 8 tezde ise veri analiz teknikleri belirtilmemiştir. Bu husus önemli bir eksiklik olarak değerlendirilmektedir. Nitel veri analizleri içerik ve betimsel analizler üzerinde yoğunlaşırken manuel analizler şeklinde gerçekleştiği dikkat çekmektedir. Karma araştırma ile yürütülen T29 kodlu tezde ise NVIVO nitel veri analiz programı üzerinden analiz yapıldığı görülmektedir. Dijitalleşen dünyada analizlerin güvenirliklerini arttırmak için bilgisayar destekli araçların kullanımı önemli olarak değerlendirilmekte ve bu tür uygulamaların tez çalışmalarına yansıtılmaması bir eksiklik olarak değerlendirilmektedir. Nicel verilerin analizinde ise SPSS programının sağladığı olanaklar üzerinden analizlerin yapıldığı görülmektedir.

\section{Araştırmanın Dokuzuncu Alt Amacına İlişkin Bulgular ve Yorum}

"Sosyal bilgiler ĕgitimi alanında tarih ve tarih ögretimi konuları üzerine yapılmış lisansüstü tezlerde ulaşılan sonuçlar nasıldır? " araştırma sorusuna ilişkin elde edilen bulgular tablo 9'da gösterilmiştir. 
Tablo 9. Tezlerde Sonuçlar

\begin{tabular}{|c|c|c|}
\hline Sonuçlar & Tezler & $f$ \\
\hline $\begin{array}{l}\text { Sosyal bilgiler dersi tarih konularının öğretiminde kullanılan } \\
\text { model, yöntem ve yaklaşımlar öğrenciler üzerinde kalıcı } \\
\text { öğrenmede, akademik başarıda bilgi, beceri, değer } \\
\text { kazandırmada olumlu değişimler meydana getirmektedir. }\end{array}$ & $\begin{array}{l}\text { T24,T69,T67,T64,T9,T20,T28, } \\
\text { T58,T53,T57,T68,T10,T45,T6, } \\
\text { T34,T37,T23,T15,T12,T32 }\end{array}$ & 20 \\
\hline $\begin{array}{l}\text { Sosyal bilgiler ders kitaplarında yer alan tarih konularının } \\
\text { içerik anlamında bazı konuları yeterince içermediği ve } \\
\text { kronolojik anlamda bütüncül olmadığı, kavramların anlaşılır } \\
\text { olmadığı için öğretim sürecinde sorunlar yaşanmaktadır. }\end{array}$ & $\begin{array}{l}\text { T60,T55,T40,T30,T27,T22,T42, } \\
\text { T13,T6,T26,T44,T43 }\end{array}$ & 12 \\
\hline $\begin{array}{l}\text { Sosyal bilgiler öğretiminde tarih konularını işlenişinde } \\
\text { ögretmenlerin görüşlerine ders saatlerinin yetersizliği, } \\
\text { konuların yoğun olması gibi nedenlerle tarih konuları yüzeysel } \\
\text { işlenmektedir. }\end{array}$ & $\begin{array}{l}\text { T39,T70,T25,T3,T1,T16,T21, } \\
\text { T38 }\end{array}$ & 8 \\
\hline $\begin{array}{l}\text { Tarihsel kanıtların kullanılması yoluyla, tarih konularında } \\
\text { ögretimin etkililiğinin artabileceği saptanmıştır. }\end{array}$ & $\mathrm{T} 11, \mathrm{~T} 36, \mathrm{~T} 49, \mathrm{~T} 56, \mathrm{~T} 65, \mathrm{~T} 41, \mathrm{~T} 2$ & 7 \\
\hline $\begin{array}{l}\text { Sosyal bilgiler ve tarih öğretiminin tarihsel süreçte yaşanan } \\
\text { toplumsal olaylardan olumsuz etkilendiğini, öğrencilerin } \\
\text { Osmanlı, Selçuklu ve İslam tarihini içerik olarak önemli } \\
\text { gördükleri, öğrencilere somut yaşantılar ile tarih bilincini } \\
\text { kazandırmanın faydalı olacağı saptanmıştır. }\end{array}$ & $\mathrm{T} 63, \mathrm{~T} 51, \mathrm{~T} 35, \mathrm{~T} 4, \mathrm{~T} 31$ & 5 \\
\hline $\begin{array}{l}\text { Tarihsel empatiye dayalı yapılan öğretim öğrencilerin } \\
\text { başarısına, tutumlarına ve kalıcı ögrenmeye katkı } \\
\text { sağlamaktadır. }\end{array}$ & T47,T48,T50,T59,T61,T29 & 6 \\
\hline $\begin{array}{l}\text { Tarihi mekânların tarih eğitimin bir parçası haline } \\
\text { getirilmesinin müfredattaki kazanımların } \\
\text { gerçekleştirilmesinde yararlı olduğu saptanmıştır. }\end{array}$ & $\mathrm{T} 52, \mathrm{~T} 33, \mathrm{~T} 18, \mathrm{~T} 72$ & 4 \\
\hline $\begin{array}{l}\text { Sözlü tarih yöntemiyle işlenen derslerde öğrenci başarısının } \\
\text { arttığı saptanmıştır. }\end{array}$ & $\mathrm{T} 66, \mathrm{~T} 71, \mathrm{~T} 19$ & 3 \\
\hline $\begin{array}{l}\text { Ülkemiz sosyal bilgiler programı; devletin istediği vatandaş } \\
\text { tipini yetiştirme hedefi açısından Suudi Arabistan öğretim } \\
\text { programı ile benzerlik göstermekte, Azerbaycan 6. ve 7. sınıf } \\
\text { tarih konularının işleniş aşamalarılla ise farklılık } \\
\text { göstermektedir. }\end{array}$ & $\mathrm{T} 5, \mathrm{~T} 8$ & 2 \\
\hline $\begin{array}{l}\text { Öğrencilerin tarihsel sorgulama, yorumlama becerilerinin ve } \\
\text { tarihsel olaylar üzerine yazılmış yazılı materyalleri (kitap, } \\
\text { dergi vs.) okumada eksikliklerinin olduğu saptanmıştır. }\end{array}$ & $\mathrm{T} 17, \mathrm{~T} 7$ & 2 \\
\hline $\begin{array}{l}\text { Sosyal bilgiler ve tarih öğretmenlerinin yurtseverlik } \\
\text { tutumlarının yüksek olduğu ve kör yurtseverlik eğilimlerinin } \\
\text { ise yapıcı yurtseverlik eğilimlerinden daha yüksek olduğu } \\
\text { görülmüştür. Öğretmenler yurtseverlik eğitimini sosyal } \\
\text { bilgiler ve tarih programlarının bir parçası olarak görmektedir. }\end{array}$ & $\mathrm{T} 14, \mathrm{~T} 46$ & 2 \\
\hline $\begin{array}{l}\text { Görme engelli sosyal bilgiler ve tarih öğretmenlerinin bilgi ve } \\
\text { iletişim teknolojilerinin kullanımı ile ilgili erişilebilirlik } \\
\text { sorunları yaşadıkları, bu alanda bilgi eksikliklerinin yine } \\
\text { görme engellilere uygun bir içerikle hizmet içi eğitimlerle } \\
\text { giderilebileceği saptanmıştır. }\end{array}$ & T54 & 1 \\
\hline Toplam & & 72 \\
\hline
\end{tabular}

Tablo 9'daki sosyal bilgiler eğitimi içerisinde tarih konulu lisansüstü tezlerin ulaştı̆ğ sonuçlar incelendiğinde; bu tezlerde en fazla ulaşılan sonucun 20 tez ile Sosyal bilgiler eğitiminde kullanılan farklı model, yöntem ve yaklaşımların öğrenciler üzerinde olumlu değişimler yaratmadaki önemi vurgulanmıştır. 12 tezde sosyal bilgiler ders kitaplarında yer alan tarih konularının içerik anlamında bazı konuları yeterince içermediği ve kronolojik anlamda bütüncül olmadığı, kavramların anlaşılır olmadığı için öğretim sürecinde sorunlar yaşandığ ortaya konmuştur. 8 tezde öğretmen görüşleriyle bazı sorunlu konulara dikkat çekilmiştir. 7 
tezde ise kanıt temelli tarih öğretiminin önemi vurgulanırken, 5 tezde önemli olan tarih konuları ve tarih bilinci geliştirmede somut deneyimlerin önemi ve sosyal bilgilerin tarihsel gelişiminde dönemsel olayların etkili olduğu ortaya konmuştur. 6 tezde tarihsel empati, 4 tezde tarihi mekanların kullanımı ve 3 tezde sözlü tarihin kullanımının öğrenci başarısında önemli bir yeri olduğu sonucuna ulaşılmıştır. Farklı ülke sosyal bilgiler öğretim programlarının karşılaştırıldığı 2 tezde benzerlik ve farklılıklar ortaya konulmuştur. Yine 2 tezde öğrencilerin tarihsel sorgulama, yorumlama becerilerinin ve tarihsel olaylar üzerine yazılmış yazılı materyalleri (kitap, dergi vs.) okumada eksikliklerinin olduğu saptanmıştır. Yurtseverlik konusunun ele alındığı 2 tezde öğretmenlerin tutumlarının yüksek olduğu ve yurttaşlık eğitiminin sosyal bilgiler içerisinde verilmesinin önemli olduğu sonucuna ulaşılmıştır. Son olarak 1 tez de ise görme engelli olan sosyal bilgiler ve tarih öğretmenlerinin bilgi ve iletişim teknolojilerine erişmekte güçlük yaşadıkları sonucuna ulaşıldığı görülmektedir.

\section{Araştırmanın Onuncu Alt Amacına İlişkin Bulgular ve Yorum}

"Sosyal bilgiler eğitimi alanında tarih ve tarih ögretimi konuları üzerine yapılmış lisansüstü tezlerde geliştirilen öneriler nelerdir?" araştırma sorusuna ilişkin elde edilen bulgular tablo 10 'da gösterilmiştir.

Tablo 10. Tezlerde Öneriler

\begin{tabular}{llc}
\hline Öneriler & Tezler & $f$ \\
\hline Öğretmenlere yönelik & T1,T6,T7,T9,T10,T11,T12,T13,T15,T16,T17,T18,T19,T20,T23, & 40 \\
& T24,T27,T28,T31,T36,T37,T38,T39,T42,T45,T47,T49, & \\
& T50,T52,T53,T56,T57,T58,T59,T61,T63,T65,T66,T68,T71 & 26 \\
Araştırmacılara Yönelik & T2,T7,T14,T17,T19,T20,T21,T34,T43,T45,T47,T48,T50,T55, & 18 \\
& T58,T59, T60,T61,T62,T63,T64,T65,T66,T67,T68,T70 & \\
Politika Yapıcılara Yönelik & T3,T7,T10,T11,T13,T15,T17,T19,T29,T38,T45,T53,T56,T60, & 11 \\
& T62,T65,T69,T72 & 10 \\
Üniversitelere Yönelik & T3,T7,T8,T10,T11,T29,T33,T41,T49,T65,T72 & 7 \\
Belirtilmemiş & T4,T5,T25,T26,T30,T32,T35,T40,T46,T51 & 3 \\
Milli Ĕ̆itim Müdürlükleri & T3,T9,T22,T33,T36,T39,T54 & 1 \\
Öğrencilere Yönelik & T17,T22,T38 & $\mathbf{1 0 6}$ \\
Gençlik ve Spor Bakanlığına & T44 & \\
\hline Toplam & &
\end{tabular}

Tablo 10'da, incelenen lisansüstü tezlerde geliştirilen önerilerin eğitim tezleri olması nedeniyle genellikle "Öğretmeler, Araştırmacılar ve Politika üretmesi beklenen kurum olarak Milli Eğitim Bakanlı̆̆g” olmak üzere başlıca üç kategoride toplandığı görülmektedir. Lisansüstünde üretilen tezlerde önerilerin sadece bir grubu hedeflemesi söz konusu olmadığı için araştırmaların doğası gereği bir çalışmanın öneriler bölümü öncelikle araştırma sonuçlarına göre ve daha sonra uygulayıcılara ve politika yapıcılara ya da spesifik gruplar varsa onlara yönelik gerçekleştirilir. $\mathrm{Bu}$ araştırmada incelenen 72 tezinde bu yapıya genel anlamda uygun olduğu söylenebilir. Tabloda frekans sayısının 106 olduğu görülmektedir. Bunun temel nedeni belirtildiği gibi, incelenen tezlerin konuları gereği öneriler bölümünde birden fazla gruba öneri getirmeyi gerektirmesinden kaynaklanmaktadır. Ancak 10 tezde öneriler bölümüne hiç yer verilmediği görülmüştür.

\section{SONUÇ, TARTIŞMA VE ÖNERÍLER}

$\mathrm{Bu}$ bölümde, araştırma alt amaçları doğrultusunda ulaşılan sonuçlar maddeler halinde diğer çalışmalar ile olan bağlantılarıyla birlikte tartışılarak ortaya konulmaya çalışılmıştır. Araştırma bulgularına göre ortaya çıkan sonuçlar şöyledir; 
Tezlerin Hazırlanma Yllı: Bu çalışmada ulaşılan ilk sonuca göre, 2000-2019 yılları arasında sosyal bilgiler eğitimi alanında tarih ve tarih öğretimi konuları üzerine yapılmış lisansüstü tezlerde en fazla tez çalışmasının yapıldığ y1l 2019 en az ise 2000, 2002, 2003 ve 2018 olduğu görülmüştür. Bu durum, sosyal bilgiler eğitimindeki tarih konularının çalışılma sayılarındaki artışın halen devam ettiğini göstermektedir. Ancak Çalık (2020) tarafindan yapılan sosyal bilgilerde tarih konuları üzerine yapılan tezlerin analizi ile ilgili çalışmada 58 tez incelenmiş ve y1l değişkeni anlamında en fazla tezin 2002 yılında 11 tez üretildiği sonucuna ulaşılmıştır. Birbirine çok benzer olan bu iki araştırma arasındaki farkın neden olduğu tam olarak bilinmemekle birlikte arama kriteri farklılığından kaynaklandığı düşünülmektedir.

Türkiye'de çeşitli alanlarda hazırlanan lisansüstü tezlerin sayısında genel bir artış olduğu belirtilmektedir (Zengin \& Çalış, 2017). Eğitim bilimlerinin bazı alanlarında ise çalışılan bazı konuların son yıllarda sayılarında azalma eğilimi söz konusu olmaktadır. Örneğin, Karakoç, Özpolat ve Kara (2018)'ın araştırmalarında en fazla tezin yapıldığı yılların sırasıyla 2012, 2008, 2007, 2013 ve 2015 olduğu görülmüştür. Ayaz ve diğ., (2015) Türkiye'de öğretmen eğitimi ile ilgili yapılmış lisansüstü tezleri incelemiş ve yapılan tezlerin genelde 2006-2009 yılları arasında yoğunlaştığını söylemişlerdir. Erdoğan (2017)'da benzer şekilde çalışma sayısı 20072013 yılları arasında yoğunlaşmış olduğunu, 2014'ten itibaren sayı olarak azalma eğilimi gösterdiğini belirtmektedir. Fakat bu çalışmadaki düzenli sayı artışı, alanın popülaritesinin devam ettiğinin de bir göstergesi olabilir.

Tezlerin Türü: Araştırma kapsamında incelenen tezlerin genellikle yüksek lisans seviyesinde kaldığı, doktora seviyesinde yeterince tez çalışması yapılmadığı/yapılamadığı, görülmektedir. $\mathrm{Bu}$ durumun sebebinin sosyal bilgiler eğitimi alanında Türkiye'de açılan lisansüstü programlardaki artış ile bağlantılı olduğu düşünülmektedir. Kaymakcı ve Öztürk (2011) ile Yaylak (2019)'ın yapmış olduğu çalışmalarda bu artışın dikkate değer olarak gerçekleştiği açıkça görülmektedir. Benzer şekilde Çalık (2020) tarafından yapılan araştırma sonucunda da yüksek lisans tezlerinin doktora tezlerinden yüksek olduğu görülmektedir.

Tezlerin Üniversitelere Göre Dağıllımı: Bu çalışmada elde edilen veriler, incelenen tezlerin çoğunlukla Marmara Üniversitesi, Gazi Üniversitesi ve Niğde Üniversitesi bünyelerinde hazırlandıklarını göstermektedir. Sosyal bilgiler eğitimi alanında hazırlanan tezler üniversiteler bazında incelendiğinde, İstanbul ve Ankara üniversiteleri dikkat çekmektedir. Konuyla ilgili bir başka araştırma sonucunda sosyal bilgilerde tarih ile ilgili konuların öğretimi üzerinde hazırlanan lisansüstü çalışmaların üniversitelere göre dağılımına bakıldığında Gazi Üniversitesi \%24,1 ile birinci, Marmara Üniversitesi \%17,2 ile ikinci, Atatürk Üniversitesi \%12,9 ile üçüncü sırada olduğu sonucuna ulaşılmışıtır (Çalık, 2020). Marmara ve Gazi üniversiteleri arasında farklılık görülmesinin nedeninin araştırmalar arasındaki örneklem farkından kaynaklandığı değerlendirilmektedir. Benzer bir bulgu daha önceki araştırmacılar tarafindan da elde edilmiş̧ir. Örneğin Okutan ve Ekşi (2007) 2000-2003 yılları arasında eğitim yönetimi alanında hazırlanan tezlerin en fazla Ankara Üniversitesi bünyesinde yapıldığını; Bıkmaz ve diğ. (2013) eğitim programları ve öğretim alanındaki tezlerin en fazla Hacettepe, Orta Doğu Teknik, Dokuz Eylül ve Ankara üniversitesi bünyesinde yoğunlaşı̆ğını; Karakoç, Özpolat ve Kara (2018) tezlerde Ankara (\%14.4), Orta Doğu Teknik (\%13.5), Anadolu (\%7.2), Hacettepe (\%6.3) üniversitelerinin; Kaymakc1 (2017)'da Gazi (\%35.71), Marmara (\%12.86) ve Karadeniz Teknik Üniversitesi (\%8.58)'nin ön plana çıktığını teyit etmektedirler. Bu durumun söz konusu üniversitelerin öğretim üyesi sayılarının yüksek olması ve buna bağlı olarak da lisansüstü öğrenci alım kapasitelerinin de fazla olması ile bağlantılı olduğu düşünülmektedir. Buradan 
hareketle, bir çalışma alanında çalışmaların sayıca fazla olması ile üniversite öğretim üyesi sayısı ve üniversite köklü geçmişi arasında bir bağlantı oluşturulabilir.

Tezlerde Çalışılan Konu: Sosyal bilgiler eğitimi alanında tarih ve tarih öğretimi konuları üzerine yapılmış lisansüstü tezler konu açısından bütüncül bir yaklaşımla değerlendirildiğinde; en çok 21 tezle sosyal bilgilerde tarih konularının öğretimi ve 12 tezle sosyal bilgiler tarih konularının öğretiminde kullanılan öğretim kuramları, yöntem ve teknikleri üzerinde yoğunlaştığı sonucuna ulaşılmıştır. Hazırlanan tezlerin çoğunluğu bu bağlamda yapılmıştır. Tarih ile ilgili konuların öğretimini inceleyen Çırak (2020) çalışmasında yöntem uygulaması, öğretim programının ve dersin değerlendirilmesi, öğretmen görüşlerinin incelenmesi konusunun daha yoğun olduğunu belirterek bu çalışmayla benzer bir sonuca ulaşmıştır. Aynı zamanda "sosyal bilgiler dersi öğretim programı öğeleri" kapsamında "değer eğitimi" ile "sosyal bilgiler dersinde kullanılan öğretim yöntemleri”" öne çıkaran Oğuz-Haçat ve Demir (2018) ve "strateji -yöntem-teknik" teması ilk sırada yer aldığını ortaya koyan Hayta ve diğ. (2020) konu alanı olarak bu çalışmaya yakın sonuçlar elde etmişlerdir.

Tezlerde Amaç: Sosyal bilgiler eğitimi alanında tarih ve tarih öğretimi konuları üzerine yapılmış lisansüstü tezlerdeki amaçlar alt problemi bağlamında ulaşılan sonuç; en fazla "Sosyal bilgiler dersi tarih konularının öğretiminde kullanılabilecek model, yöntem ve yaklaşımlar" etrafında toplandığı görülmüştür. En az çalışılan amaçlar arasında ise görme engeli tarih ve sosyal bilgiler öğretmenlerinin tarih ve sosyal bilgiler eğitiminde bilgi ve iletişim teknolojilerini kullanma stratejilerini, sosyal bilgiler ve tarih öğretmenlerinin yurtseverlik ve eğitimi hakkındaki tutumlarını ortaya koymak yer almaktadır. Bu araştırma ile aynı sorun kapsamında ele alınan Çırak (2020)'ın çalışmasında tarih konulu tezlerin amaçlarının incelenmediği görülmektedir.

Tezlerde Yöntem: Sosyal bilgiler eğitimi alanında tarih ve tarih öğretimi konuları üzerine hazırlanmış lisansüstü tezler yöntem açısından değerlendirildiğinde sırasıyla en fazla tercih edilen nitel araştırma (\%45.8), nicel araştırma (\%33.3), karma araştırma yöntemleri (\%11.1) ve araştırma yöntemlerinin belirtilmediği (\%9.7) görülmüştür. Tarih eğitimi, öğretimi ve yazıcılığ konularında hazırlanmış yüksek lisans tezleri inceleyen Hayta ve diğ. (2020) bu çalışma ile benzer sonuçlara ulaşmıştır. Nicel yöntemle yapılan çalışmaların oranının nitel yöntem ve karma yöntemle yapılan araştırmalara göre daha yüksek olduğu belirleyen Çırak (2020) bu çalışmadan farklı sonuçlara ulaşmıştır. Çırak (2020)'a göre sosyal bilgilerde tarih ile ilgili konuların öğretimi üzerine hazırlanan tez çalışmalarında araştırma yöntemi olarak nicel yöntem çalışmalarının oranı \%55.2; nitel yöntem çalışmalarının oranı $\% 34.5$ ve karma yöntemle yapılan araştırmaların oranı ise \%10.3 olarak verilmiştir. Eğitim bilimleri alanında hazırlanan yüksek lisans derecesindeki tezlerin incelendiği bazı araştırmalarda tezlerin büyük oranda nicel araştırma yöntemiyle hazırlandığı görülmüştür (Tavşancıl \& diğ., 2010; Şahin \& diğ., 2013; Sönmez \& Özcan, 2020).

Eğitim bilimleri alanında genellikle tarama deseninin, öğretmen yetiştirme çalışmalarında ise deneysel desenlerin kullanıldığı (Fazlığulları \& Kurul, 2012; Karakoç, Özpolat \& Kara, 2018) belirtilmektedir. Tarih öğretimiyle ilgili olarak hazırlanan tezlerin yöntemlerinde ise en fazla tarama yöntemi (\%44.29) kullanıldığı belirtilmektedir (Kaymakc1, 2017). Sönmez \& Özcan (2020), inceledikleri lisansüstü tezlerin yöntemlerine ilişkin olarak nitel yöntemle yürütülen tezlerin yarısından fazlasında, karma yöntemle yürütülen tezlerin yarısında araştırma desenine ilişkin bilginin verilmemiş olmasını çok dikkat çekici bir durum olarak değerlendirmektedirler. Bunun sebebinin, tez çalışması yapan araştırmacıların araştırma modeli konusunda yeterli düzeyde bilgisi olmamasıyla ilgili olabileceği değerlendirilmiştir (Karadağ, 2010). Bu 
çalı̧̧mada elde edilen bulgular da bu durumu destekler nitelikte olduğundan, çalışmalarda yöntemle ilgili eksikliklerin nedenlerinin temelde bilgi eksikliği olduğu şeklinde bir değerlendirme yapılmaktadır.

Tezlerde Çalışma Grubu / Örneklem: Sosyal bilgiler eğitimi alanında tarih ve tarih öğretimi konuları üzerine yapılmış lisansüstü tezlerde tercih edilen çalışma grupları bir bütün olarak değerlendirildiğinde, en çok sosyal bilgiler öğretmenleri ve 7. sinıf öğrencileri iken en az tercih edilen çalışma grubunun ise tarih öğretmenleri ve ilköğretim öğretmenlerinden oluştuğu görülmüsşür. $\mathrm{Bu}$ araştırma kapsamında incelenen tezlerin hiçbirinde akademisyenlerin örneklem ya da çalışma grubuna dâhil edilmemesi dikkat çekicidir. Sosyal bilgilerde tarih ile ilgili konuların öğretimi inceleyen Çırak (2020) çalışmasında öğrencilerin \%21 ile birinci sırada yer aldığını, hemen ardından gelen öğretmenlerin oranının \%15, öğretmenler ve öğrencilerin oranının \% 11 , öğretmenler-ders kitapları ve öğretmenler-müfettişler oranının ise \%1,7 ile en az çalı̧̧lan örneklem grubu olduğunu ortaya koyarak bu çalışmadan farklı sonuçlara ulaşmıştır. Ancak sosyal bilgiler eğitimi üzerine yapılan doktora tezlerini inceleyen Oğuz-Haçat ve Demir (2018) doktora tezlerinin örneklem grubunu en fazla 7. sınıf ögrencileri ile hazırlanan çalı̧̧malar oluşturduğunu belirterek çalışmamızla benzer bir sonuca ulaşmıştır. Katılımcılar olarak en fazla öğretmenler (Sönmez \& Özcan, 2020), öğretim elemanları ve öğretmen adayları (Ayaz, Oral \& Söylemez, 2015), öğretmen adayları, öğretmenler ve öğretim elemanları (Karakoç, Özpolat \& Kara, 2018) olarak belirtilen çalışmaların olduğu görülmektedir. Burada çalışılan grupların farklı olmasının, çalışılan konunun doğası, özellikleri ve veri toplama koşulları ile bağlantılı olduğu değerlendirmektedir. Örneğin, 2020 yılında tüm dünyada başlayan pandemi ile birlikte araştırmacıların yüz yüze eğitimden daha farklı katılımcı gruplarını ve yöntemleri tercih ettikleri bir döneme doğru girildiği görülmektedir. Elbette ki pandeminin eğitime olan yansımalarının portresini çizebilmek için daha zamana ihtiyaç olmakla birlikte, önemli bir değişimi de beraberinde getireceği açıktır. Bu durum öğretim üyelerinin hali hazırda devam eden ve yönettikleri tez çalışmalarına da yansımaktadır.

Tezlerde Kullanılan Veri Toplama Araçları: Sosyal bilgiler eğitimi alanında tarih ve tarih öğretimi konuları üzerine hazırlanmış lisansüstü tezlerde veri toplama aracı açısından çeşitliliğin olduğu görülmektedir. Hazırlanan tezlerde en çok kullanılan veri toplama aracı; sırasıyla görüsşme formu, doküman taraması ve başarı testinin tercih edildiği görülmektedir. Çırak (2020) çalışmasında sosyal bilgilerde tarih konularının öğretiminde veri toplama aracı olarak en fazla anket tekniği, test/ölçek tekniği ve doküman incelemesi olduğunu belirterek çalışmamızdan farklı sonuçlara ulaşmıştır. Oğuz-Haçat ve Demir (2018) ise incelediği tezlerde en çok tercih edilen veri toplama aracının görüşme/mülakat olduğunu belirterek bu çalışmayı destekler bir sonuca ulaşmıştır.

Sönmez ve Özcan(2020) lisansüstü tezlerin verilerinin toplamda en fazla anket ( $\mathrm{f}=51)$ ve görüş̧e ( $\mathrm{f}=51$ ) tekniği ile toplandığı, en az ise odak grup tekniği $(\mathrm{f}=4)$ ile toplandığını; Karakoç, Özpolat ve Kara (2018), tezlerde kullanılan veri toplama araçları olarak anket (\%28.7) ve görüşmenin (\%22.2) ön plana çıktığını; Erdoğan (2017), tezlerde en çok başarı testi (\%30.9), tutum ölçeği (18.1) ve görüşme formu (\%10.9) kullanıldığını belirtmektedir.

$\mathrm{Bu}$ durumu etkileyen faktörler arasında da, lisansüstü öğrencinin akademik pozisyonu ve çalı̧̧a hayatları gibi özelliklerin belirleyici olduğu söylenebilir. Çünkü akademik bir çalı̧̧ada hangi veri toplama araçlarıyla çalışma yapılacağı katılımcı sayısııın da belirleyici olmakta ve bu durum araştırmacıları erişilebilir evrene götürmektedir. 
Tezlerde Kullanılan Veri Analiz Yöntemleri: Bu araştırma verileri, gerek nitel gerekse nicel araştırma desenlerinde kullanılan veri analizi yöntemi olarak betimsel yöntem ağırlıklı analiz yöntemlerinin en çok tercih edilen veri analiz yöntemi olduğunu ortaya koymuştur. Bu bulgular Kaymakc1 ve Er (2009)'in bulgularıyla örtüşmektedir.

Sosyal bilgiler eğitimi alanında tarih ve tarih öğretimi konuları üzerine hazırlanmış lisansüstü tezlerde kullanılan veri analiz yöntemleri bir bütün olarak değerlendirildiğinde tezlerin büyük bir bölümünde nitel veri analiz yöntemlerinin öncelikle tercih edildiği görülmektedir.

Tezlerde Ulaşılan Sonuçlar: Bu alt amaç araştırma kapsamında analiz edilirken araştırmaya dâhil edilmesi noktasında çekincelerin olduğu bir sürecin sonunda eklenmiştir. Çünkü her araştırma birbirinden farklı sonuçlar ortaya koymakta ve bu sonuçları kategorilere dönüştürmeden sunmak bir meta-sentez çalışmasını içinden çıkılmaz bir hale sokmaktadır. Ancak araştırma kapsamında incelenen tezlerin sonuçlarından hiç bahsetmemek ise araştırmanın eksik kalması anlamına gelmektedir. Ayrıca bulguların okunabilir ve anlaşılabilir boyutta sunulabilmesi araştırmanın geçerliğini arttırmaktadır. Belirtilen bu gerekçelerle bulgulara dayalı olarak ortaya çıkan sonuçlardan bazıları; 20 tezin çağdaş öğrenme yaklaşımlarının ve yöntemlerinin işe koşulduğu araştırmaların sonuçlarından öğrencilerin olumlu kazanımlar elde ettiğini göstermekte ve 12 tezde ise sosyal bilgiler program/ders kitaplarının tarih konularını içeren kısımlarında kavramsallaştırma, bütüncül olmamak gibi sorunların olduğu şeklindedir.

Sosyal bilgiler eğitimi içerinde tarih konulu tezlerdeki eğilimler genel olarak değerlendirildiğinde sosyal bilgiler eğitimi sayesinde "tarih" anlayışında "tarih öğretimi" yönelimi anlamında olumlu gelişmeler sağlanmış olsa da tarih öğretiminin gelişimi için alternatif konu ve araştırma yöntemlere ihtiyaç olduğu söylenebilir.

Tezlerde Geliştirilen Öneriler: İncelenen tezlerde geliştirilen önerilerin en fazla öğretmeler (40), araştırmacılar (26) ve politika üretmesi beklenen kurum olarak Milli Eğitim Bakanlığı (18) olmak üzere başlıca üç kategoride toplandığı sonucuna ulaşılmıştır. Daha sonra sırasıyla 11 tezde üniversitelere 7 tezde Milli Eğitim Müdürlükleri ve 3 tezle öğrencilere yönelik önerilerde bulunulmuştur. 10 tezde ise herhangi bir öneri bölümüne yer verilmediği dikkat çekmektedir. Buna göre öğretmenlere getirilmiş öneri sayısının fazla olması, sosyal bilgiler eğitimi içindeki tarih konularının öğretimi ve geliştirilmesi çalışmalarında öğretmenin üzerine düşen sorumluluklar olduğu gerçeğini ortaya koymaktadır.

Genel olarak değerlendirildiğinde, literatürde belirtilen bazı sorunlar arasında, tezlerin hem nitelik hem de nicelik yetersiz olduğu ve geliştirilmesi gerektiği (Akyol \& Yavuzkurt, 2016; Apaydın \& Erol, 2017), tez konularında sürekli birbirini tekrar eden konuların çalışılması, özgün ve yeni çalışmaların ortaya konulmasında kısır bir durum ile karşılaşılması (Aydın \& Uysal, 2011) olarak belirtilmektedir. Buna göre, sosyal bilgiler eğitiminde kalitenin arttırılmasının yollarının salt sayısal olarak çalışma sayısının artmasına bağlı olmadığı bilinmeli, fakat çalışma sayılarının arttırımasının önemli bir belirleyici olduğu da unutulmamalidir.

\section{Öneriler}

Araştırma sonuçlarına göre diğer araştırmacı ve uygulayıcılara yönelik öneriler ise şunlar olabilir; 
- Sosyal bilgiler eğitimi tarih konuları bağlamında her ne kadar kanıt temelli tarih anlayış1, sözlü tarih, yerel tarih, tarihsel empati gibi çağdaş tarih bakış açının ele alınmış olduğu görülse de tezlerin birbirine çok yakın olduğu, çoğu zaman aynı konunun benzer şekilde tekrarlandığ 1 dikkat çekmektedir. Sosyal bilgiler eğitimi içerisinde yeni, orijinal ve alana katkı sağlayacak konuların tercih edilmesinde fayda olacağı düşünülmektedir.

- Sosyal bilgiler eğitimi içerisinde yapılan tezler incelendiğinde tezlerin yöntem bölümleri açısından oldukça yetersiz olduğu görülmüştür. İncelenen tezlerde yöntemle ilgili önemli sorunlar görülmesi nedeniyle, lisansüstü öğrencilerinin aldığ 1 metodoloji derslerine daha fazla ağırlık verilmesi, alt birimlere ayrılması (nicel yöntemler, nitel yöntemler vs.) suretiyle öğrencilerin bu konu ile ilgili eksikliklerinin giderilmesi gerekmektedir. Yapılacak tezlerin yöntem bölümlerine daha fazla önem verilmesinin tezleri daha nitelikli bir yapıya kavuşturacağ 1 düşünülmektedir.

- Tezlerde nitel araştırma yöntemi kullanılmasına rağmen nitel araştırma desenlerine (durum çalışması, eylem araştırması vb.) çalışmaların yok denecek kadar az olduğu dikkat çekmektedir. Lisansüstü çalışmalarda farklı nitel araştırma desenlerinin kullanılması sağlanabilir.

- Tezlerde veri toplama araçlarının birbirine benzer araçlardan oluştuğu görülmüştür. Çoklu veri toplama teknikleriyle alan zenginleştirilebilir.

- Çalışma grubu anlamında incelenen tezlerin hiçbirinde akademisyen gruba yer verilmediği görülmüştür. Bu anlamda akademisyen grupla çalışmaların yapılması başka perspektiflerin katılmasıyla alana katkı sağlayabilir.

- Bu çalışmada sosyal bilgiler eğitiminde tarih konusunda yapılmış olan lisansüstü tezler incelenmiştir. İleriki araştırmalarda bu konuda yayınlanan makaleler incelenebilir.

Araştırmacıların Katkı Oranı Beyanı: Birinci yazar, tasarımlama, kavramsallaştırma, literatür taraması, yazım ve düzenleme, makale yükleme ve dergi yazışmalarını yapmıştır. Çalışmaya katk1 oran1 \%50'dir. İkinci yazar, veri toplama, verilerin analizi ve puanlama, inceleme ve düzenleme çalışmalarını yapmıştır. Çalışmaya katkı oranı \%50’dir.

\section{KAYNAKÇA}

Akdağ, H. (2009). Sosyal bilgilerin tanımı, amacı, önemi ve Türkiye'deki yeri. R. Turan, A. M. Sünbül ve H. Akdağ (Ed.). Sosyal bilgiler ögrretiminde yeni yaklaşımlar-I içinde. PegemA Yayıncılık.

Aksoy, B. Sözmez, Ö. F., Merey, Z. \& Kaymakcı, S. (2009). Sosyal bilgiler alanında yapılan yüksek lisans ve doktora tezlerinin değerlendirilmesi. IV. Sosyal Bilimler Eğitimi Kongresi, 7-9 Ekim İstanbul. https://www.pegem.net/Akademi/kongre_detay.aspx?id=10609605

Akyol, B. \& Yavuzkurt, T. (2016). Türkiye'de lisansüstü tezlerde eğitim denetimi. Uluslararası Türkçe Edebiyat Kültür Eğitim Dergisi, 5 (2), 908-926.

Apaydın, Y. \& Erol, İ. (2017). Türkiye'de eğitim ekonomisi alanında yapılan lisansüstü tezlerin incelenmesi, Marmara Üniversitesi Atatürk Ĕ̌itim Fakültesi Eğitim Bilimleri Dergisi, 45, 23-41.

Ata, B. (2007). Sosyal bilgiler öğretim programı. Öztürk, C. (Ed.), Hayat bilgisi ve sosyal bilgiler ögretimi içinde, PegemA Yayıncilık.

Ata, B. (2009). Sosyal bilgiler ünitesi kavramı üzerine bazı düşünceler. R. Turan, A. M. Sünbül ve H. Akdağ (Ed.), Sosyal Bilgiler Öğretiminde Yeni Yaklaşımlar-1 içinde, (s.25-42). PegemA Yayıncılık. 
Ayaz, M. F., Behçet, O. \& Söylemez, M. (2015). Türkiye'de öğretmen eğitimi ile ilgili yapılmış lisansüstü tezlerin değerlendirilmesi. İlköğretim Online, 14 (2), 787-802.

Aydın, A. \& Uysal, Ş. (2011). Evaluation of doctoral theses on educational administration in Turkey and abroad, in terms of subjects, methods, and results. Eurasian Journal of Educational Research, 42, 1-14.

Bıkmaz, F. H., Aksoy, E., Tatar, Ö. \& Altınyüzük, C. A. (2013). Eğitim programları ve öğretim alanında yapılan doktora tezlerine ait içerik çözümlemesi (1974-2009). Eğitim ve Bilim Dergisi, 38 (68), 288-303.

Canbulat, T., Avcı, G. \& Sipahi S. (2016). ABD ve Kanada'da sosyal bilgiler eğitimi alanındaki tezlerin değerlendirilmesi. Ahi Evran Üniversitesi Kırşehir Eğitim Fakültesi Dergisi (KEFAD), 17(2), 351-370.

Coşkun, İ., Dündar, Ş. \& Parlak, C. (2014). Türkiye'de özel eğitim alanında yapıllmış lisansüstü tezlerin çeşitli değişkenler açısından incelenmesi. Ege Eğitim Dergisi, 15 (2), 375-396.

Creswell, J. W. (2016). Araştırma deseni. Nitel, nicel ve karma yöntem yaklaşımları. (Çev. Ed. S. B. Demir). Eğiten Kitap.

Cücük, E. (2017). Türkiye'de "eğitim tarihi”" alanında yapılmış doktora tezlerinin incelenmesi. (Yayınlanmamış Yüksek Lisans Tezi). Gaziantep Üniversitesi Sosyal Bilimler Enstitüsü, Gaziantep, Türkiye.

Çalık, M. \& Sözbilir, M. (2014). İçerik analizinin parametreleri. Eğitim ve Bilim, 39 (174). 33-38.

Çırak, A. (2020). Sosyal bilgilerde tarih ile ilgili konuların öğretimi üzerine 1999-2019 yılları arası yapılan tezlerin analizi. Gazi Üniversitesi Gazi Eğitim Fakültesi Dergisi, 40 (3), 1219-1242.

Demircioğlu, İ. H. (2010). Tarih öğretiminde öğrenci merkezli yaklaşımlar. Anı Yayıncılık.

Dilek, A., Baysan, S. \& Öztürk, A. A. (2018). Türkiye'de sosyal bilgiler eğitimi üzerine yapılan yüksek lisans tezleri: Bir içerik analizi çalışması. Türkiye Sosyal Araştırmalar Dergisi, 22 (2), 581-602.

Dilek, D. (2002). Tarih derslerinde öğrenme ve düşünce gelişimi. PegemA Yayınc1lı.

Erdoğan, Y. (2017). What does research tell us about trends in dissertations on PBL? Universal Journal of Educational Research, 5 (6), 972-988.

Fazlığulları, O. \& Kurul, N. (2012). Türkiye'deki eğitim bilimleri doktora tezlerinin özellikleri. Mehmet Akif Ersoy Üniversitesi Eğitim Fakültesi Dergisi, (24) 43-75.

Geçit, Y. \& Kartal, A. (2010). Türkiye'deki sosyal bilgiler eğitimi araştırma konuları üzerine bir inceleme. International Conference on New Trend in Education and Their Implications, 11-13 November Antalya. http://www.iconte.org/FileUpload/ks59689/File/19.pdf

Günay, D. (2018). Türkiye'de lisansüstü eğitim ve lisansüstü eğitime felsefi bir bakış. Üniversite Araştırmaları Dergisi, 1 (2), 71-88.

Gürdoğan-Bayır, Ö., Kılıç, Z. \& Balbağ, N. L. (2018). Vatandaşlık eğitimine yönelik yapılan lisansüstü çalışmaların incelenmesi. Tay, B. (Ed.), 7. Uluslararası Sosyal Bilgiler Eğitimi Sempozyumu Bildiriler Kitabl içinde (ss. 69- 81). Kırşehir: Ahi Evran Üniversitesi.

Hayta, N., Karabağ, G. \& Gövercin, A. (2020). Türkiye'de tarih eğitimi ile ilgili yapıllmıș lisansüstü tezlerin değerlendirilmesi. Turkish History Education Journal, 9 (1), 248-262. DOI: 10.17497/tuhed.705751

Karadağ, E. (2010). Eğitim bilimleri doktora tezlerinde kullanılan araştırma modelleri: Nitelik düzeyleri ve analitik hata tipleri. Kuram ve Uygulamada Ĕgitim Yönetimi, 16 (1), 49-71.

Karakoç, B., Turan Özpolat, E. \& Kara, K. (2018). Türkiye'de öğretmen yetiştirme konusunda yapılan lisansüstü tezlerin incelenmesi, Akdeniz Eğitim Araştırmaları Dergisi, 12 (24), 313 - 333.

Kaymakcı, S. \& Er, H. (2009). Türk inkılâp tarihi ve Atatürkçülük konularının öğretimi üzerine yapılan tezlerin analizi. Cumhuriyet Tarihi Araştırmaları Dergisi, 5 (9), 165-180.

Kaymakc1, S. \& Öztürk, T. (2011). The panorama of social studies education in Turkey. e-Journal of New World Sciences Academy, 6 (2), 1852-1867.

Kaymakcı, S. (2017). Türkiye'de tarih öğretiminin yönelimi üzerine bir değerlendirme. Kastamonu Eğitim Dergisi, 25 (6), 2153-2172. 
Oğuz-Haçat, S. \& Demir, S. B. (2018). Sosyal bilgiler eğitimi üzerine yapılan doktora tezlerinin değerlendirilmesi (2002-2018). Avrasya Uluslararası Araştırmalar Dergisi, $6 \quad$ (15), 948-973. DOI:10.33692/avrasyad.510136

Okutan, M. \& Ekşi, A. (2007). 2000-2003 yılları arasında eğitim yönetimi teftişi planlaması ve ekonomisi alanında yapılmış olan yüksek lisans tez özetleri çalışması. 16. Ulusal Eğitim Bilimleri Kongresi. Gaziosmanpaşa Üniversitesi, Tokat.

Oruç, Ş. \& Ulusoy, K. (2008). Sosyal bilgiler öğretimi alanında yapılan tez çalışmaları. Selçuk Üniversitesi Ahmet Keleşoğlu Eğitim Fakültesi Dergisi, 26, 121 -132.

Öner, G. \& Öner, D. (2017). Sosyal bilgiler eğitiminde coğrafya konuları üzerine yapılmış lisansüstü tezlere yönelik bir analiz ve bibliyografya çalışması. Boğaziçi Üniversitesi Ĕ̆itim Dergisi, 34 (2), 13-34.

Öztürk, C. \& Dilek, D. (2005). Hayat bilgisi ve sosyal bilgiler öğretim programları. C. Öztürk ve D. Dilek (Ed.), Hayat Bilgisi ve Sosyal Bilgiler Öğretimi içinde, PegemA Yayıncılık.

Sönmez, N. \& Özcan, B. (2020). Türkiye'de ilkokulda kaynaş̧ırma eğitimiyle ilgili yapılan lisansüstü tezlerin betimsel incelemesi. Yaşadıkça Eğitim, 34 (1), 1-27. DOI: 10.33308/26674874.2020341121

Sönmez, Ö. F., Merey, Z. \& Kaymakcı, S. (2009). Vatandaşlık ve insan hakları alanında yapılan yüksek lisans ve doktora tezlerinin değerlendirilmesi. I. Uluslararası Avrupa Birliği, Demokrasi, Vatandaşlık ve Vatandaşlı Eğitimi Sempozyumu, 28-30 Mayıs, Uşak. https: //www.Pegem.net/Akademi /sempozyumbildiri_detay.aspx $?$ id $=50291$

Şahin, D., Calp, Ş., Bulut, P. \& Kuşdemir, Y. (2013). Sınıf öğretmenliği eğitimi bilim dalında yapılmış lisansüstü tezlerin çeşitli kriterlere göre incelenmesi. Zeitschrift für die Welt der Türken/Journal of World of Turks, $5(3), 187-205$.

Tavşancıl, E., Erdem, D., Yalçın, N., Yıldırım, Ö. \& Bilican, S. (2010). Examination of data analyses used for master's theses in educational sciences. Procedia Social and Behavioral Sciences, 9, 1467-1474.

Turan, R. \& Akdağ, H. (2017). Sosyal bilgiler öğretiminde yeni yaklaşımlar III. PegemA Yayıncılık.

Turan, R. \& Ulusoy K. (2011). Sosyal bilgiler disiplininde tarihin yeri ve önemi. R. Turan ve K. Ulusoy (Ed.), Sosyal Bilgilerin Temelleri içinde, (s.138-155). Maya Akademi Yayınları.

Üstüner, M. \& Cömert, M. (2008). Eğitim yönetimi teftişi planlaması ve ekonomisi anabilim dalı lisansüstü dersleri ve tezlerine ilişkin bir inceleme. Kuram ve Uygulamada Eğitim Yönetimi, 55, 497-515.

Yaylak, E. (2019). Türkiye'de sosyal bilgiler eğitiminin yükseköğretimdeki durumu. OPUS-Uluslararası Toplum Araştırmaları Dergisi, 11 (18), 800-838. DOI: 10.26466/opus.545800.

Yıldırım, A. \& Şimşek, H. (2011). Sosyal bilimlerde nitel araştırma yöntemleri. Seçkin Yayıncılık.

Zengin, O. \& Çalış, N. (2017). Türkiye'de sosyal hizmet araştırması: son 10 yılda sosyal hizmet anabilim dallarında yazılan tezler üzerine bir inceleme. Insan ve Toplum Bilimleri Araştırmaları Dergisi, 6 (2), 1260-1273.

\section{EK-1: Araştırma Kapsamında İncelenen Tezler ve Kodları}

\section{Yüksek Lisans Tezleri}

T1. İlköğretim Altıncı Sınıflar Sosyal Bilgiler Tarih Ünitelerinin İşlenişinde Öğretmenlerin Kullandıkları Öğretim Yöntemleri

T2. İlköğretim Sosyal Bilgiler Dersi Tarih Konularını Öğretiminde Tarihsel Kanıtların Etkililiği

T3. İlköğretim II. Kademe Sosyal Bilgiler Dersi Tarih Konularının Öğretiminde, Öğretmen ve Müfettiş Görüşlerinin Değerlendirilmesi (Konya İlköğretim Okulları Örneğinde)

T4. 1998 Yılında Yürürlüğe Giren İlköğretim Sosyal Bilgiler Müfredatında Tarih Konularının İçerik Bakımından Değerlendirilmesi

T5. Türkiye'de İlköğretim 6. ve 7. Sınıf Sosyal Bilgiler Dersi İle Azerbaycan'da 6. ve 7. Sinıf Tarih Derslerinin Muhteva Yönünden Karşılaştırılması 
T6. İlköğretim Hayat Bilgisi Sosyal Bilgiler Müfredatlarının Tarih Konularında Eğitim Materyali Olarak Resmin Kullanılmasi

T7. Sosyal Bilgiler Dersinde 7. Sınıf Öğrencilerinin Tarih Öğrenme Beceri Düzeyler

T8. Suudi Arabistan'daki Mutavassıt (Ortaokul)1. Sınıf Tarih, Coğrafya ve Vatandaşlık Eğitimi Programları İle Türkiye'deki 6. Sınıf Sosyal Bilgiler Eğitimi Programının Karşılaştırılması

T9. İlköğretim 7. Sınıf Sosyal Bilgiler Dersi Tarih Konularının Öğretiminde İşbirlikçi Öğrenme Yönteminin Öğrenci Başarısına Etkisi

T10. İlköğretim Sosyal Bilgiler Dersi Tarih Konularının Öğretiminde Resimlendirilmiş Öykülerin Tarihsel Düşünme Becerilerinin Gelişimine Etkisi

T11. İlköğretim 4. Sınıf Sosyal Bilgiler Tarih Konularının Öğretiminde Kanıt Temelli Öğrenme Modeli: Bir Aksiyon Araştırma

T12. Yeni Öğretim Programında İlköğretim 4.Sınıf Sosyal Bilgiler Dersi Tarih Konularının Çoklu Zekâ İle Öğretimi (Afyonkarahisar Örneği)

T13. Yerel Tarih Konularının Sosyal Bilgiler Derslerinde Uygulanması; Karşılaşılan Güçlükler ve Çözüm Önerileri (Yozgat Örneği)

T14. Yurtseverlik Eğitimi: Sosyal Bilgiler ve Tarih Öğretmenlerinin Tutum ve Algılarına Yönelik Bir Çalışma (Tokat İli Örneği)

T15. Sosyal Bilgiler Dersi Tarih Konularının Öğretiminde Siyasetnamelerden Faydalanmanın Akademik Başarıya Etkisi

T16. İlköğretim 7. Sınıf Sosyal Bilgiler "Türk Tarihinde Yolculuk" Ünitesindeki Kazanımların Öğretmen Görüşlerine Göre Değerlendirilmesi

T17. İlköğretim Sekizinci Sınıf Öğrencilerinin Tarihsel Okuryazarlık Durumlarının Belirlenmesi

T18. Sanayi Müzelerinin Tarih Öğretiminde Kullanım Durumu: Rahmi M. Koç Müzesi Örneği

T19. Sosyal Bilgiler Dersinde Örnek Bir Sözlü Tarih Uygulaması

T20. İlköğretim Beşinci Sınıf Öğretmenlerinin Sosyal Bilgiler Dersinde Tarih Konuları Üzerinde Oluşturdukları Metaforların Söylem Analizi Tekniği İle İncelenmesi

T21. Sosyal Bilgiler Öğretmenlerinin Tarih Konuları İle İlgili Soru Sorma Becerilerinin Bloom Taksonomisine Göre Değerlendirilmesi

T22. 6. ve 7.Sınıflardaki Türkçe Ders Kitaplarında Yer Alan Metinlerin Sosyal Bilgiler Dersinin Tarih Konuları İle İlişkilendirilmesinin Eski ve Yeni Müfredat Açısından Karşılaştırmalı Olarak İncelenmesi

T23. Sosyal Bilgiler Öğretiminde Tarihi Romanların Kullanımının Öğrencilerin Akademik Başarısı Üzerine Etkisi

T24. Sosyal Bilgiler Dersinde Tarih Konularının Öğretiminde Proje Tabanlı Öğrenme Yaklaşımı

T25. İlköğretim 7. Sınıf Sosyal Bilgiler Öğretim Programında Yer Alan Konuların Tarih Bilinci Oluşturmadaki Etkililiğinin Öğretmen Görüşlerine Göre Değerlendirilmesi (Elazığ İli Örneği)

T26. Erken Çocukluk Döneminde Sosyo-Kültürel Eğitim: Türk Tarihine Ait Bazı Önemli Olay ve Olgular Üzerine Bir Eylem Araştırması

T27. Sosyal Bilgiler Öğretmenlerinin Tarih Konularının Öğretiminde Kullandıkları Öğrenci Merkezli Yöntemlerle İlgili Karşılaş̧ıkları Sorunlar

T28. İlköğretim Sosyal Bilgiler Dersi Tarih Konularının Öğretiminde Aktif Öğrenme Modelleri, Öğrenci ve Öğretmen Görüşleri Doğrultusunda Değerlendirilmesi

T29. İlköğretim 7. Sınıf Sosyal Bilgiler Dersinde Tarihsel Empatiye Dayalı Rol Oynama Yönteminin Akademik Başarıya Etkisi

T30. Türkiye'de Sosyal Bilgiler ve Tarih Öğretiminde Selçuklu Tarihi'nin Yeri ve Önemi

T31. İlköğretim Öğrencilerinde Tarihsel Önem ve Anlamlılık Kavramının Gelişimi 
T32. 6.Sınıf Sosyal Bilgiler Dersinde Tarih Konularının Çoklu Zekâ Kuramına Göre Öğretilmesinin Öğrenci Başarısına Etkisi

T33. İstanbul İli Ölçeğinde Tarihi Mekânların Ortaokul Sosyal Bilgiler Dersi Tarih Konularının Öğretimindeki Yeri ve Önemi

T34. Sosyal Bilgiler Dersi Tarih Konuları Kazanımlarının Gerçekleştirilmesinde Tarihi Hikâyelerin Kullanımı

T35. Eğitim Enstitülerinin Tarih Eğitimindeki Yeri

T36. Sosyal Bilgiler Dersi Tarih Konularının Öğretiminde Birinci Elden Kaynakların Kullanımı (7. Sınıf Örneği)

T37. Tarihi Hikâyelerin İlkokul 4. Sınıf Sosyal Bilgiler Dersinin Öğretimindeki Önemi

T38. İlkokul 4. Sınıf Sosyal Bilgiler Dersi Tarih Konularında Değer Öğretimine İlişkin Sınıf Öğretmeni Görüşleri

T39. Ortaokul 7. Sınıf Sosyal Bilgiler Dersinde Tarih Konularının Öğretimine İlişkin Öğretmen Görüşlerinin İncelenmesi (Ağrı İli Örneği)

T40. Türkiye Cumhuriyeti İnkılâp Tarihi ve Atatürkçülük Derslerinde "İstiklâl Yolu" nun Öğretimi: (Mevcut Ders Kitapları, Öğretmen ve Öğrenci Görüşleri ve Çağdaş Yayınlar Işı̆̆ında Yeni Bir Etkinlik Paketi Tasarımı)

T41. Sosyal Bilgiler Dersinde Tarihi ve Sanatsal Mekân Kullanımına İlişkin Öğretmen Görüşleri

T42. Yerel Tarihin Sosyal Bilgiler Öğretiminde Değişim ve Sürekliliği Algılama Becerisi Üzerindeki Etkisinin Değerlendirilmesi

T43. Sosyal Bilgiler Eğitiminin Doğasına Uygun Tarih Öğretimi

T44. Sosyal Bilgiler Öğretmenlerinin Tarihi Kültürel Miras Eğitimine İlişkin Görüşleri (Denizli Şehri Örneği)

T45. Sosyal Bilgiler Dersinde Yer Alan Tarih Konularının Öğretiminde Drama Kullanımı: Bir Eylem Araştırması

T46. Sosyal Bilgiler ve Tarih Öğretmenlerinin Yurtseverlik Tutumları İle Temel Değer Yönelimleri Arasındaki İlişki

Tt47. Sosyal Bilgiler Dersinde Tarihsel Empati Etkinliklerinin Öğrencilerin Akademik Başarı, Kalıcılık ve Derse Karşı Tutumlarına Etkisi

T48. Sosyal Bilgiler Dersinde Tarihsel Empatiye Dayalı Etkinliklerin Öğrencilerin Tarihsel Empati Becerilerine ve Başarılarına Etkisi

T49. Ortaokul Sosyal Bilgiler Dersinde Tarihsel Kanıt Kullanımının Öğrencilerin Tutumlarına Etkisi ve Öğretmen Görüşleri

T50. Sosyal Bilgiler Dersinde Yaratıı Drama Yöntemiyle Tarihsel Empati Becerisinin Kazandırılmasına Yönelik Etkinlik Temelli Bir Eylem Araştırması

T51. Türkiye'de Sosyal Bilgiler Eğitiminin Tarihi Gelişimi

T52. Sosyal Bilgiler Dersinde Tarihi Mekân Gezilerinin Öğrencilerin Akademik Başarılarına Etkisi: Aksaray İli Örneği

T53. Tarih Eğitiminde Tarihsel Film ve Dizilerin Kullanımı ve Sosyal Bilgiler Dersi Tarih Üniteleri İçin Öğretim Programı Temelli Bir Materyal Kılavuzu Geliştirme Çalışması

T54. Görme Engelli Tarih ve Sosyal Bilgiler Öğretmenlerinin Tarih ve Sosyal Bilgiler Eğitiminde Bilgi ve İletişim Teknolojilerini Kullanma Stratejileri

T55. Sosyal Bilgiler Öğretmen Adaylarının 7. Sınıf Sosyal Bilgiler Dersi Tarih Kavramlarına İlişkin Kavram Yanılgılarının Tespiti

T56. Tarih Eğitiminde Minyatür Kullanımının Öğrenme Üzerindeki Etkileri

T57. Sosyal Bilgiler Dersi Tarih Konularının Öğretiminde Oyunla Öğretim Uygulamaları (Deneysel Bir Çalışma)

T58. 4.Sınıf Sosyal Bilgiler Dersinde Tarih Konularının Aktif Öğrenmeye Dayalı Etkinlik Temelli Öğretimin Tarihsel Düşünme Becerisinin Gelişimine ve Akademik Başarıya Etkisi

T59. Tarihsel Empati Etkinlikleriyle İşlenen Sosyal Bilgiler Derslerinin Öğrenci Ürün ve Görüşlerine Göre İncelenmesi 
T60. 8. Sınıf T.C İnkılâp Tarihi ve Atatürkçülük Dersinde ve Ders Kitabında Hatay Meselesinin Yeri ve Önemi

T61. Ortaokul 7. Sınıf Sosyal Bilgiler Dersi Kültür ve Miras Öğrenme Alanının Öğretiminde Tarihsel Empatinin Kullanılması: Bir Eylem Araştırması

T62. Sosyal Bilgiler 6. Sınıf Tarih Konularının Öğretilmesinde Senaryo Tabanlı Öğrenme Yönteminin Öğrencilerin Akademik Başarısına Etkisi

T63. Sosyal Bilgiler Dersi 5.Sınıf Konularının Tarih Bilinci Oluşturmadaki Etkililiğinin Öğretmen Görüşlerine Göre Değerlendirilmesi

\section{Doktora Tezleri}

T64. Sosyal Bilgiler Öğretiminde Yapıcı Öğrenme ve Otantik Değerlendirme Yaklaşımlarının Öğrencilerin Akademik Başarı, Kalıcılık ve Sosyal Bilgiler Dersine Yönelik Tutumlarına Etkisi

T65.Sosyal Bilgiler Öğretiminde Tarihsel Yazılı Kanıtların Kullanım

T66. Sosyal Bilgiler Öğretiminde Sözlü Tarih Etkinliklerinin Öğrenci Başarı, Beceri ve Tutumlarına Etkisi

T67. Sosyal Bilgiler Dersinde Tarih Bilinci Oluşturmada Dizgeli Öğretimin Etkililiği

T68. İlköğretim Sosyal Bilgiler Öğretiminde Temsilî Resim Kullanımıyla Tarihsel Düşünme Becerilerinin Geliştirilmesi

T69. Tarih Öğretmenlerinin Tarih Eğitimdeki Yeni Yaklaşımlara İlişkin Görüşlerinin Çeşitli Değişkenler Açısından İncelenmesi Ankara Örneği

T70. Sosyal Bilgiler Dersi Kapsamında Öğretmenlerin Tarih Konularının Öğretimine İlişkin Görüşlerinin Belirlenmesi

T71. Sosyal Bilgiler Derslerinde Bir Öğrenme ve Öğretme Yöntemi Olarak Sözlü Tarih

T72. Tarihi Mekân Kullanımının Öğretmen Adaylarının Tarih Bilinci ve Eski Türk Eserlerine İlişskin Tutumlarına Etkisi 


\section{EXTENDED ABSTRACT}

\section{Trends in Graduate Thesis prepared in the field of Social Studies Education in Turkey: A Meta-Synthesis Study}

\section{Introduction}

History subjects and its' teaching have a crucial place in social studies education. History teaching is an area that stands out in terms of meeting the data produced by the science of history with the societies and raising the awareness of the societies. It is known that history subjects have a special place among the social science disciplines that make up the social studies curriculum in Turkey. The purpose of this study is to examine graduate theses and trends in them comprehensively in terms of different variables conducted in social studies education in the context of history and history education in Turkey.

\section{Method}

A meta-synthesis was used in accordance with the purpose of this study. Meta-synthesis studies are studies in which only a small number of studies are handled and an in-depth examination, and only qualitative studies or mixed studies are evaluated. Considering the document review process, the research data of the graduate theses on history and history teaching prepared within the scope of social studies education were obtained from the YÖK national theses database. The total number of theses accessed is 72,63 of them are master's and 9 are doctoral dissertations. An imprint document / thesis definition catalog containing the research subquestions of each thesis was created by the researchers. 72 theses were transferred to the MAXQDA 2020 qualitative data analysis program with tags created from T1 to T72 for content analysis.

\section{Findings and Results}

According to the results obtained in this study, it was seen that the most thesis studies were made in the graduate theses between 2000 and 2019, and the least was 2000, 2002, 2003 and 2018. It was found that the theses generally remain at the master's level and there is not enough thesis work at the doctoral level. The theses are mostly prepared by Marmara, Gazi and Niğde Universities. When the postgraduate theses are evaluated with a holistic approach in terms of subject; it was concluded that they focus on the teaching theories, methods and techniques. According to the finding in the context of the objectives of sub-problems, theses mostly gathered around models, methods and approaches that can be used in teaching history subjects. When the theses were evaluated in terms of methods, it was seen that the most preferred ones are qualitative research $(45.8 \%)$, secondly quantitative research $(33.3 \%)$, thirdly mixed research methods $(11.1 \%)$ and there are studies research that methods were not specified $(9.7 \%)$. When the study groups preferred in postgraduate theses were evaluated as a whole, it was seen that the most preferred study group was social studies teachers and $7^{\text {th }}$ grade students, while the least preferred study group was history teachers and primary education teachers. There is diversity in terms of data collection tool in postgraduate theses. The most used data collection tool in theses is the interview forms. These research data revealed that descriptive method-weighted analysis methods were preferred as the data analysis method used in both qualitative and quantitative research designs. It was also concluded that the suggestions developed in the 
analyzed theses were mostly grouped into three main categories: teachers, researchers, and the Ministry of National Education.

\section{Suggestions}

Although some qualitative research models are used in some theses, there are almost no studies on qualitative research designs such as case study, action research, etc. It is considered that differentiation of qualitative patterns will contribute to the field. The data collection tools in theses consist of similar tools. The area can be enriched with multiple data collection techniques. None of the theses examined in terms of the study group include the academic group. In this sense, conducting studies with academicians can contribute to the field by adding other perspectives. In this study, postgraduate theses on history in social studies education were examined. Articles published on this subject can be examined in future research. 